Supporting Information

for

\title{
Mechanistic Insights into C-H Oxidations by Ruthenium(III)-Pterin Complexes: Impact of Basicity of the Pterin Ligand and Electron Acceptability of the Metal Center on the Transition States
}

Hiroumi Mitome, Tomoya Ishizuka, Hiroaki Kotani, Yoshihito Shiota, ${ }^{\dagger}$ Kazunari Yoshizawa ${ }^{\dagger}$ and Takahiko Kojima*

Department of Chemistry, University of Tsukuba, 1-1-1 Tennoudai, Tsukuba, Ibaraki 305-8571, Japan

${ }^{\dagger}$ Institute for Materials Chemistry and Engineering, Kyushu University, Motooka, Nishi-Ku, Fukuoka 819-0395, Japan. 


\section{Experimental Section.}

\section{Determination of the $\mathrm{p} K_{\mathrm{a}}$ values}

$\mathrm{UV}$-vis spectroscopic titration of $2-\mathrm{H}^{+}$, which was formed by addition of 1 eq of $\mathrm{TfOH}$, was performed with use of $\mathrm{Me}_{3} \mathrm{Py}$ as a base for the determination of $\mathrm{p} K_{\mathrm{a}}$ values of $2-\mathrm{H}^{+}$. A solution of $\mathrm{Me}_{3} \mathrm{Py}(37.9 \mathrm{mM})$ in $\mathrm{MeCN}$ was added dropwise to a $\mathrm{MeCN}$ solution $(3.0 \mathrm{~mL})$ of $2-\mathrm{H}^{+}(20.1 \mu \mathrm{M})$ in a quartz cell and the UV-vis spectrum was measured after each addition. The absorbance change at $430 \mathrm{~nm}$ (Figure S2a) was monitored and analyzed using eq S1:

$$
\begin{aligned}
& A-A_{0}=\left(\varepsilon_{2-\mathrm{H}^{+}}-\varepsilon_{2}\right)\left[K_{1}\left(\left[\mathrm{Me}_{3} \mathrm{Py}\right]_{0}+\left[\mathbf{2}-\mathrm{H}^{+}\right]_{0}\right)-\left\{K_{1}^{2}\left(\left[\mathrm{Me}_{3} \mathrm{Py}\right]_{0}+\left[\mathbf{2}-\mathrm{H}^{+}\right]_{0}\right)^{2}-4 K_{1}\left(K_{1}-\right.\right.\right. \\
& \begin{array}{l}
\text { 1) } \left.\left.\left[\mathrm{Me}_{3} \mathrm{Py}\right]_{0}\left[2-\mathrm{H}^{+}\right]_{0}\right\}^{1 / 2}\right] / 2\left(K_{1}-1\right) \\
(\mathrm{S} 1)
\end{array}
\end{aligned}
$$

where $A_{0}$ refers to the absorbance of $2-\mathrm{H}^{+}$at the wavelength and $K_{1}$ represents the equilibrium constant of the reaction between $2-\mathrm{H}^{+}$and $\mathrm{Me}_{3} \mathrm{Py} ; \varepsilon_{2-\mathrm{H}^{+}}=2340, \varepsilon_{2}=7960$ at $430 \mathrm{~nm}$. Based on eq S1, $K_{1}$ was determined to be $(4.08 \pm 0.02) \times 10^{-2}$. Thus, the $\mathrm{p} K_{\mathrm{a}}$ value of $2-\mathrm{H}^{+}$was calculated using the $K_{1}$ value obtained and the $\mathrm{p} K_{\mathrm{a}}$ value of $\mathrm{Me}_{3} \mathrm{Py}$ $(14.98)^{1}$ based on eq $\mathrm{S} 2$.

$\mathrm{p} K_{\mathrm{a}}=-\log K_{1}+\mathrm{p} K_{\mathrm{a}}\left(\mathrm{HMe}_{3} \mathrm{Py}^{+}\right)$

The $\mathrm{p} K_{\mathrm{a}}$ of $\mathbf{2}-2 \mathrm{H}^{+}$was determined through a similar procedure using trifluoromethane-sulfonic acid (TfOH) as an acid. A solution of $\mathrm{TfOH}(56.5 \mathrm{mM})$ in $\mathrm{MeCN}$ was added dropwise to a $\mathrm{MeCN}$ solution $(3.0 \mathrm{~mL})$ of $2-\mathrm{H}^{+}(17.4 \mu \mathrm{M})$ in a quartz cell, and UV-vis spectra were measured after each addition. The absorbance change at $549 \mathrm{~nm}$ (the green trace in Figure S2b) was analyzed using eq S3:

$$
\begin{aligned}
& A^{\prime}-A_{0}{ }^{\prime}=\left(\varepsilon_{2-\mathrm{H}^{+}}-\varepsilon_{2-2 \mathrm{H}^{+}}\right)\left[K_{2}\left([\mathrm{TfOH}]_{0}+\left[\mathbf{2}-\mathrm{H}^{+}\right]_{0}\right)-\left\{K_{2}^{2}\left([\mathrm{TfOH}]_{0}+\left[\mathbf{2}-\mathrm{H}^{+}\right]_{0}\right)^{2}-\right.\right. \\
& \left.\left.4 K_{2}\left(K_{2}-1\right)[\mathrm{TfOH}]_{0}\left[\mathbf{2}-\mathrm{H}^{+}\right]_{0}\right\}^{1 / 2}\right] / 2\left(K_{2}-1\right)
\end{aligned}
$$

where $A_{0}$ ' refers to the absorbance of $2-\mathrm{H}^{+}$at the wavelength and $K_{2}$ is the equilibrium constant of the reaction between $2-\mathrm{H}^{+}$and TfOH; $\varepsilon_{2-\mathrm{H}^{+}}=9390, \varepsilon_{2-2 \mathrm{H}^{+}}=2400$ at $549 \mathrm{~nm}$. Based on eq $\mathrm{S} 3, K_{2}$ was determined to be $19 \pm 2$. Thus, the $\mathrm{p} K_{\mathrm{a}}$ value of $2-2 \mathrm{H}^{+}$was 
calculated on the basis of the $K_{2}$ value obtained and the $\mathrm{p} K_{\mathrm{a}}$ value of $\mathrm{TfOH}(2.6)^{2}$ based on eq $\mathrm{S} 4$.

$\mathrm{p} K_{\mathrm{a}}=\log K_{2}+\mathrm{p} K_{\mathrm{a}}(\mathrm{TfOH})$

UV-vis titrations of $\mathbf{1}-\mathrm{H}^{+}$, which was formed by addition of 1 eq of $\mathrm{TfOH}$, were performed with use of $\mathrm{Me}_{3} \mathrm{Py}$ as a base for the determination of $\mathrm{p} K_{\mathrm{a}}$ values of $1-\mathrm{H}^{+}$via a similar procedure to that of $\mathbf{1}-\mathrm{H}^{+}$. A solution of $\mathrm{Me}_{3} \mathrm{Py}(37.9 \mathrm{mM})$ in $\mathrm{MeCN}$ was added dropwise to a MeCN solution $(3.0 \mathrm{~mL})$ of $\mathbf{1}-\mathrm{H}^{+}(19.6 \mu \mathrm{M})$ in a quartz cell and UV-vis spectrum was measured after each addition (Figure S2c). The absorbance change at 430 $\mathrm{nm}$ (Figure S2d) was analyzed using eq S5:

$$
\begin{aligned}
& A^{\prime \prime}-A_{0}{ }^{\prime \prime}=\left(\varepsilon_{1-\mathrm{H}^{+}}-\varepsilon_{1}\right)\left[K_{3}\left(\left[\mathrm{Me}_{3} \mathrm{Py}\right]_{0}+\left[\mathbf{1}-\mathrm{H}^{+}\right]_{0}\right)-\left\{K_{3}^{2}\left(\left[\mathrm{Me}_{3} \mathrm{Py}\right]_{0}+\left[\mathbf{1}-\mathrm{H}^{+}\right]_{0}\right)^{2}-\right.\right. \\
& \left.4 K_{3}\left(K_{3}-1\right)\left[\mathrm{Me} \mathrm{Py}_{0}\left[\mathbf{1}-\mathrm{H}^{+}\right]_{0}\right\}^{1 / 2}\right] / 2\left(K_{3}-1\right)
\end{aligned}
$$

where $A_{0}$ "' refers to the absorbance of $1-\mathrm{H}^{+}$at the wavelength and $K_{3}$ represents the equilibrium constant of the reaction between $1-\mathrm{H}^{+}$and $\mathrm{Me}_{3} \mathrm{Py} ; \varepsilon_{2-\mathrm{H}^{+}}=9970, \varepsilon_{2}=14870$ at $430 \mathrm{~nm}$. Based on eq $\mathrm{S} 5, K_{3}$ was determined to be $5.4 \pm 0.3$. Thus, the $\mathrm{p} K_{\mathrm{a}}$ value of 1- $\mathrm{H}^{+}$was calculated using the $K_{3}$ value obtained and the $\mathrm{p} K_{\mathrm{a}}$ value of $\mathrm{Me}_{3} \mathrm{Py}(14.98)^{1}$ based on eq S6.

$\mathrm{p} K_{\mathrm{a}}=-\log K_{3}+\mathrm{p} K_{\mathrm{a}}\left(\mathrm{HMe}_{3} \mathrm{Py}^{+}\right)$

DFT Calculations. To calculate activation energies for the $\mathrm{C}-\mathrm{H}$ bond dissociation of indene by the Ru(III)-pterin complexes $\left(\mathbf{1}_{\mathrm{OX}}\right.$ and $\left.\mathbf{2}_{\mathrm{OX}}\right)$, we performed DFT calculations. We optimized local minima on the potential energy surfaces using the B3LYP method. ${ }^{3}$ For the Ru atom, we used the SDD basis sets, ${ }^{4}$ and for the $\mathrm{H}, \mathrm{C}, \mathrm{N}, \mathrm{O}$, and $\mathrm{Cl}$ atoms, we used the D95** basis set. ${ }^{5}$ Vibration frequencies were systematically computed in order to ensure that on a potential energy surface each optimized geometry corresponds to a local minimum that has no imaginary frequency. The Gaussian 09 program package ${ }^{6}$ was used for all DFT calculations. 


\section{References}

(1) Kaljurand , I.; Kütt, A.; Sooväli, L.; Rodima, T.; Mäemets, V.; Leito. I.; Koppel, I. A. J. Org. Chem. 2005, 70, 1019.

(2) Izutsu, K. Acid-Base Dissociation Constants in Dipolar Aprotic Solvents; Blackwell Scientific: Boston, MA, 1990.

(3) (a) Becke, A. D. Phys. Rev. A 1988, 38, 3098. (b) Lee, C.; Yang, W.; Parr, R. G. Phys. Rev. B 1988, 37, 785 .

(4) Dolg, M.; Stoll, H.; Preuss, H. Theor. Chim. Acta 1993, 85, 441.

(5) Dunning, T. H.; Hay, P. J. In Modern Theoretical Chemistry; Schaefer, H. F., III, Ed.; Plenum: New York, 1976; Vol. 3, pp 1-27.

(6) Gaussian 09, Revision D.01, Frisch, M. J.; Trucks, G. W.; Schlegel, H. B.; Scuseria, G. E.; Robb, M. A.; Cheeseman, J. R.; Scalmani, G.; Barone, V.; Mennucci, B.; Petersson, G. A.; Nakatsuji, H.; Caricato, M.; Li, X.; Hratchian, H. P.; Izmaylov, A. F.; Bloino, J.; Zheng, G.; Sonnenberg, J. L.; Hada, M.; Ehara, M.; Toyota, K.; Fukuda, R.; Hasegawa, J.; Ishida, M.; Nakajima, T.; Honda, Y.; Kitao, O.; Nakai, H.; Vreven, T.; Montgomery, J. A., Jr.; Peralta, J. E.; Ogliaro, F.; Bearpark, M.; Heyd, J. J.; Brothers, E.; Kudin, K. N.; Staroverov, V. N.; Kobayashi, R.; Normand, J.; Raghavachari, K.; Rendell, A.; Burant, J. C.; Iyengar, S. S.; Tomasi, J.; Cossi, M.; Rega, N.; Millam, J. M.; Klene, M.; Knox, J. E.; Cross, J. B.; Bakken, V.; Adamo, C.; Jaramillo, J.; Gomperts, R.; Stratmann, R. E.; Yazyev, O.; Austin, A. J.; Cammi, R.; Pomelli, C.; Ochterski, J. W.; Martin, R. L.; Morokuma, K.; Zakrzewski, V. G.; Voth, G. A.; Salvador, P.; Dannenberg, J. J.; Dapprich, S.; Daniels, A. D.; Farkas, Ö.; Foresman, J. B.; Ortiz, J. V.; Cioslowski, J.; Fox, D. J. Gaussian, Inc., Wallingford CT, 2009. 


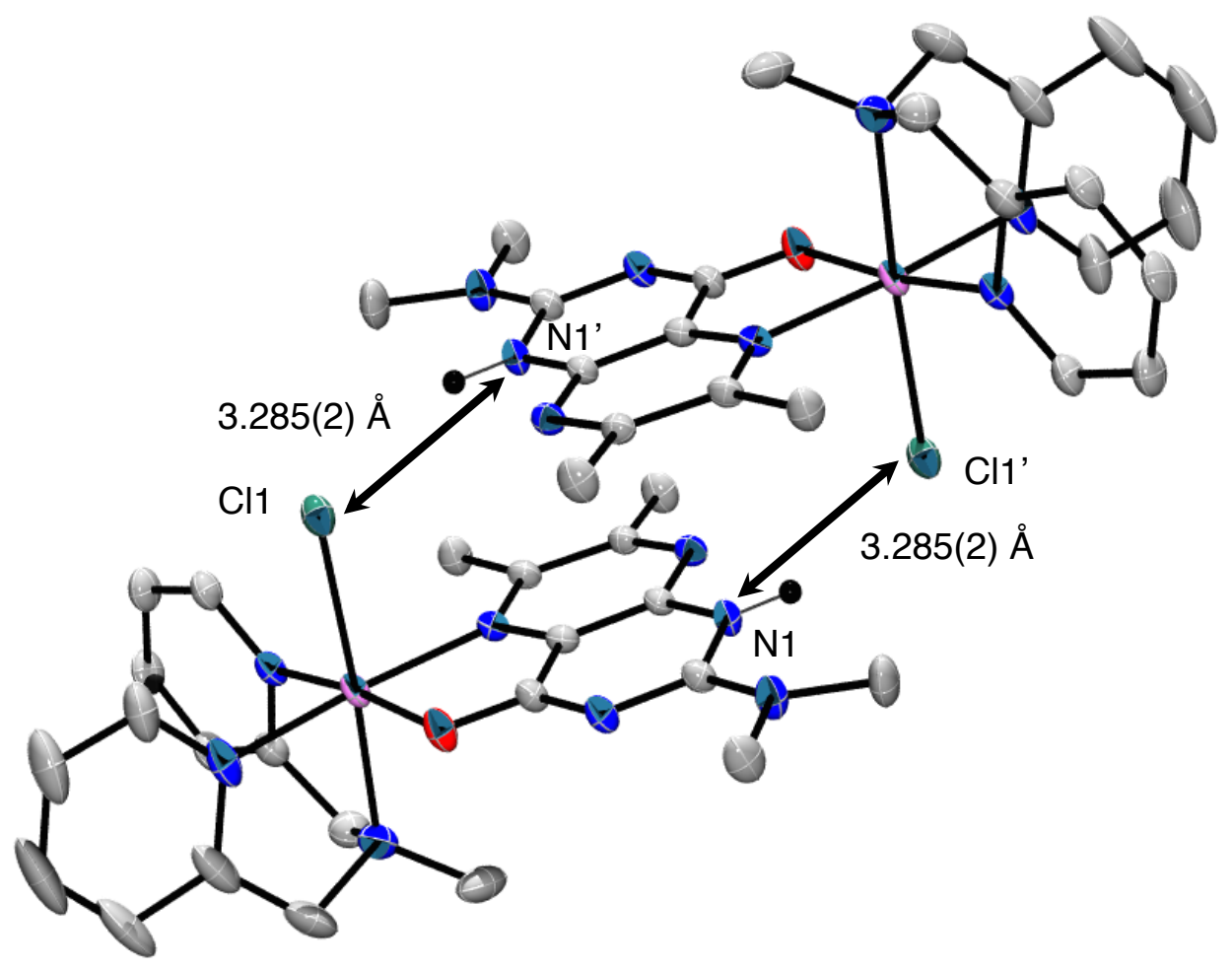

Figure S1. Hydrogen bonding between the chloride ligand and N1-H observed in the crystal structure of $\mathbf{2}-\mathrm{H}^{+} \cdot \mathrm{PF}_{6}$. Hydrogen atoms except that at $\mathrm{N} 1$ and counter ions are omitted for clarity. 
(a)

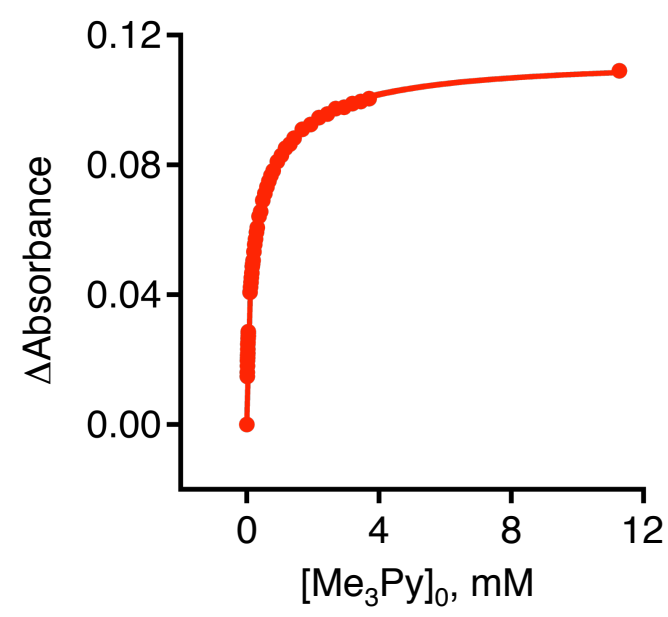

(c)

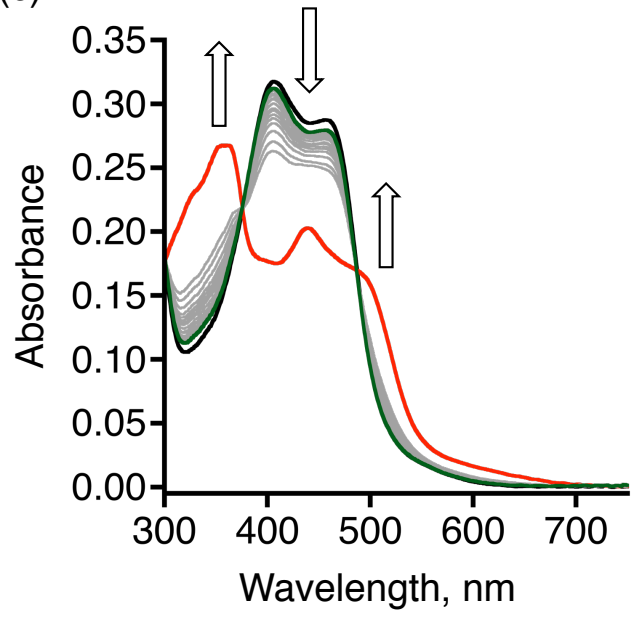

(b)

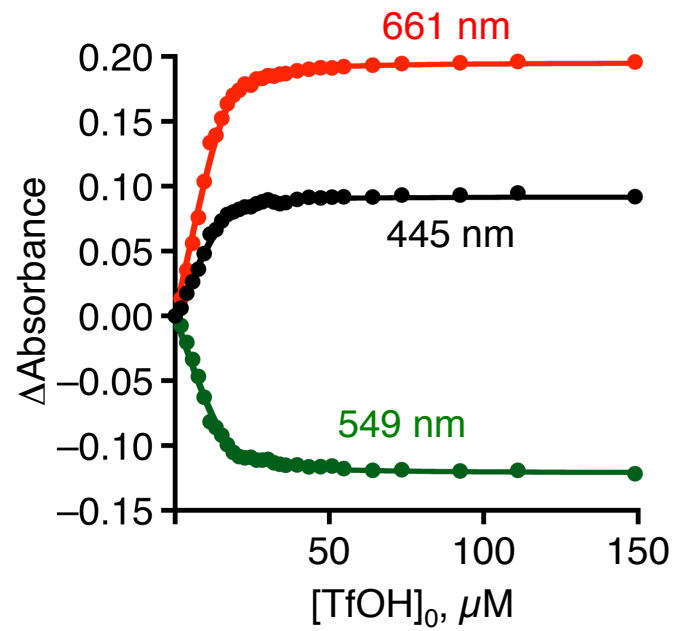

(d)

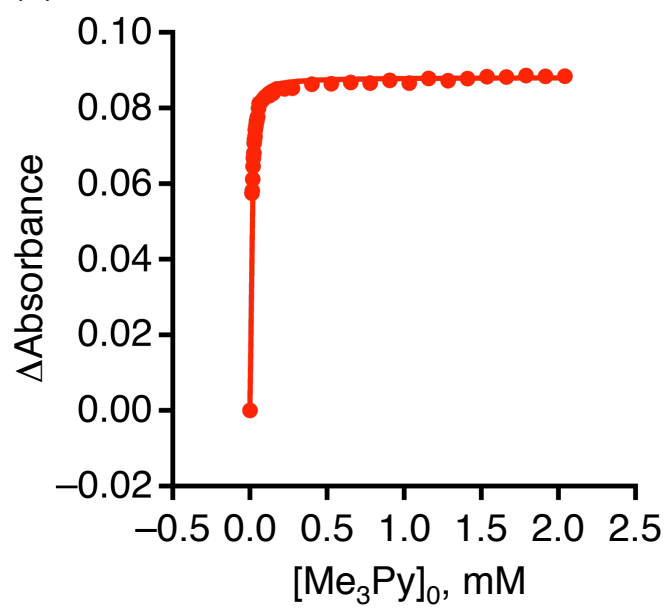

Figure S2. (a) Absorbance change at $430 \mathrm{~nm}$ in the course of spectroscopic titration of 2- $\mathrm{H}^{+}$with 2,4,6-trimethylpyridine $\left(\mathrm{Me}_{3} \mathrm{Py}\right)$ in $\mathrm{MeCN}$ at $296 \mathrm{~K}\left(\left[2-\mathrm{H}^{+}\right]_{0}=20.1 \mu \mathrm{M}\right)$; (b) absorbance changes at selected wavelengths (red: $661 \mathrm{~nm}$, black: $445 \mathrm{~nm}$, green: 549 $\mathrm{nm}$ ) in the course of spectroscopic titration of $2-\mathrm{H}^{+}$with $\mathrm{TfOH}$ in $\mathrm{MeCN}$ at $296 \mathrm{~K}$ $\left(\left[2-\mathrm{H}^{+}\right]_{0}=17.4 \mu \mathrm{M}\right)$. Absorption spectral change (c) and the absorbance change at 430 $\mathrm{nm}(\mathrm{d})$ in the course of titration of $\mathbf{1}-\mathrm{H}^{+}$with $\mathrm{Me}_{3} \mathrm{Py}$ at $296 \mathrm{~K}\left(\left[\mathbf{1}-\mathrm{H}^{+}\right]_{0}=19.6 \mu \mathrm{M}\right)$. 

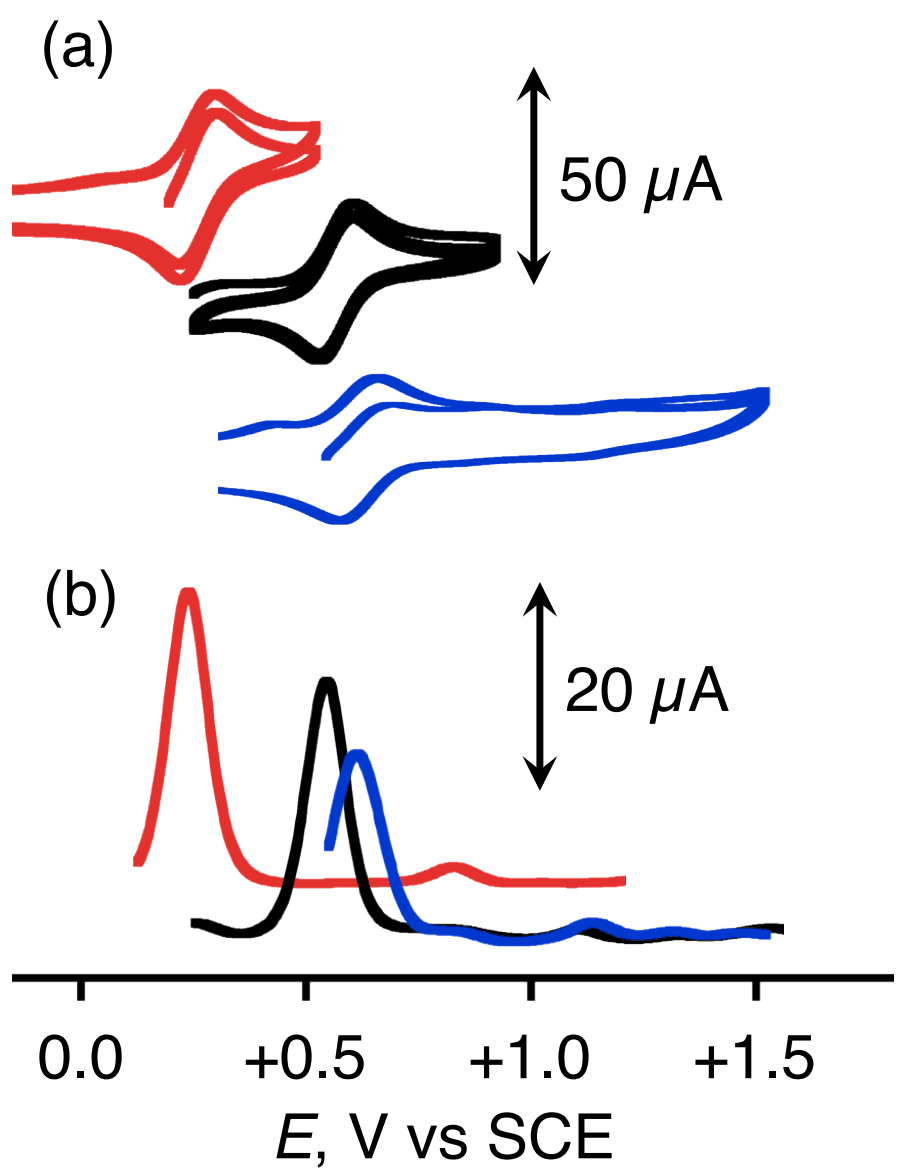

Figure S3. (a) Cyclic and (b) differential-pulse voltammograms of 2 (red, $1.0 \mathrm{mM}$ ), 2- $\mathrm{H}^{+}$(black, $1.0 \mathrm{mM}$ ) and $\mathbf{2}-2 \mathrm{H}^{+}$(blue, $1.0 \mathrm{mM}$ ) in MeCN containing 0.1 M TBAPF 6 as an electrolyte at room temperature. Working electrode: Pt disk. Counter electrode: $\mathrm{Pt}$ wire. Reference electrode: $\mathrm{Ag} / \mathrm{AgNO}_{3}$ in $\mathrm{MeCN}$. Scan rate for $\mathrm{CV}: 0.1 \mathrm{~V} / \mathrm{s}$. 
(a)

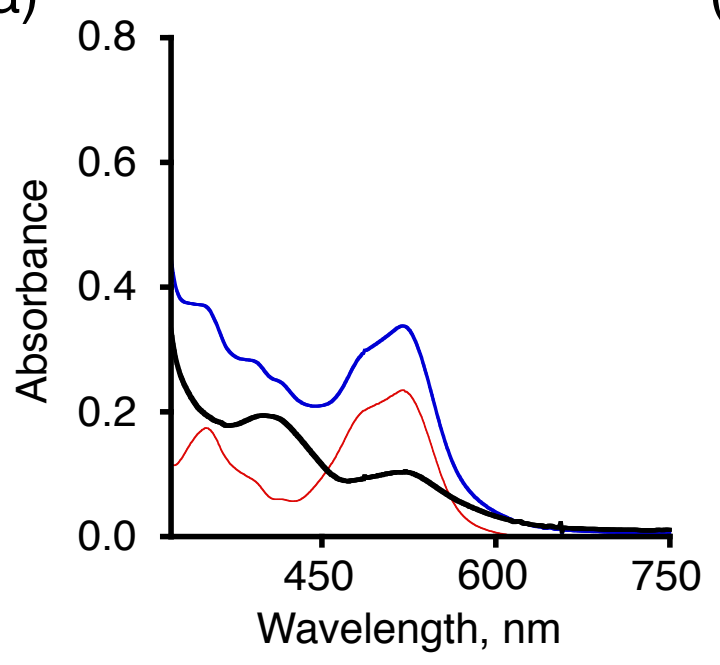

(b)

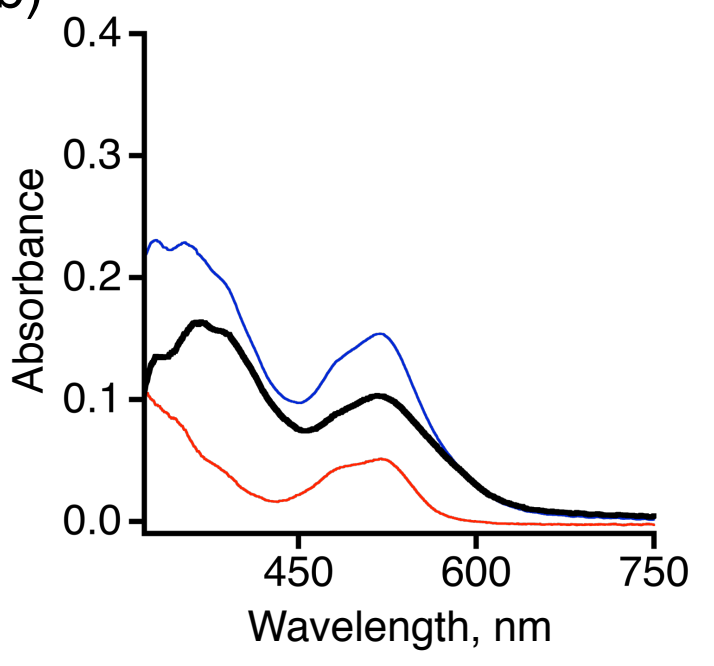

Figure S4. UV-vis spectra of the reaction mixtures of (a) $\mathbf{1}(32.0 \mu \mathrm{M})$ and $\left[\mathrm{Fe}^{\mathrm{III}}(\mathrm{bpy})_{3}\right]^{3+}$ $(32.0 \mu \mathrm{M})$ and (b) $2(17.4 \mu \mathrm{M})$ and $\left[\mathrm{Fe}^{\mathrm{III}}(\mathrm{bpy})_{3}\right]^{3+}(17.4 \mu \mathrm{M})$ in $\mathrm{MeCN}$ at room temperature (blue traces), and $\left[\mathrm{Fe}^{\mathrm{II}}(\mathrm{bpy})_{3}\right]^{2+}$ in $\mathrm{MeCN}$ at room temperature (red traces), and differential spectra (black traces) obtained by subtracting the red traces from the blue traces. 

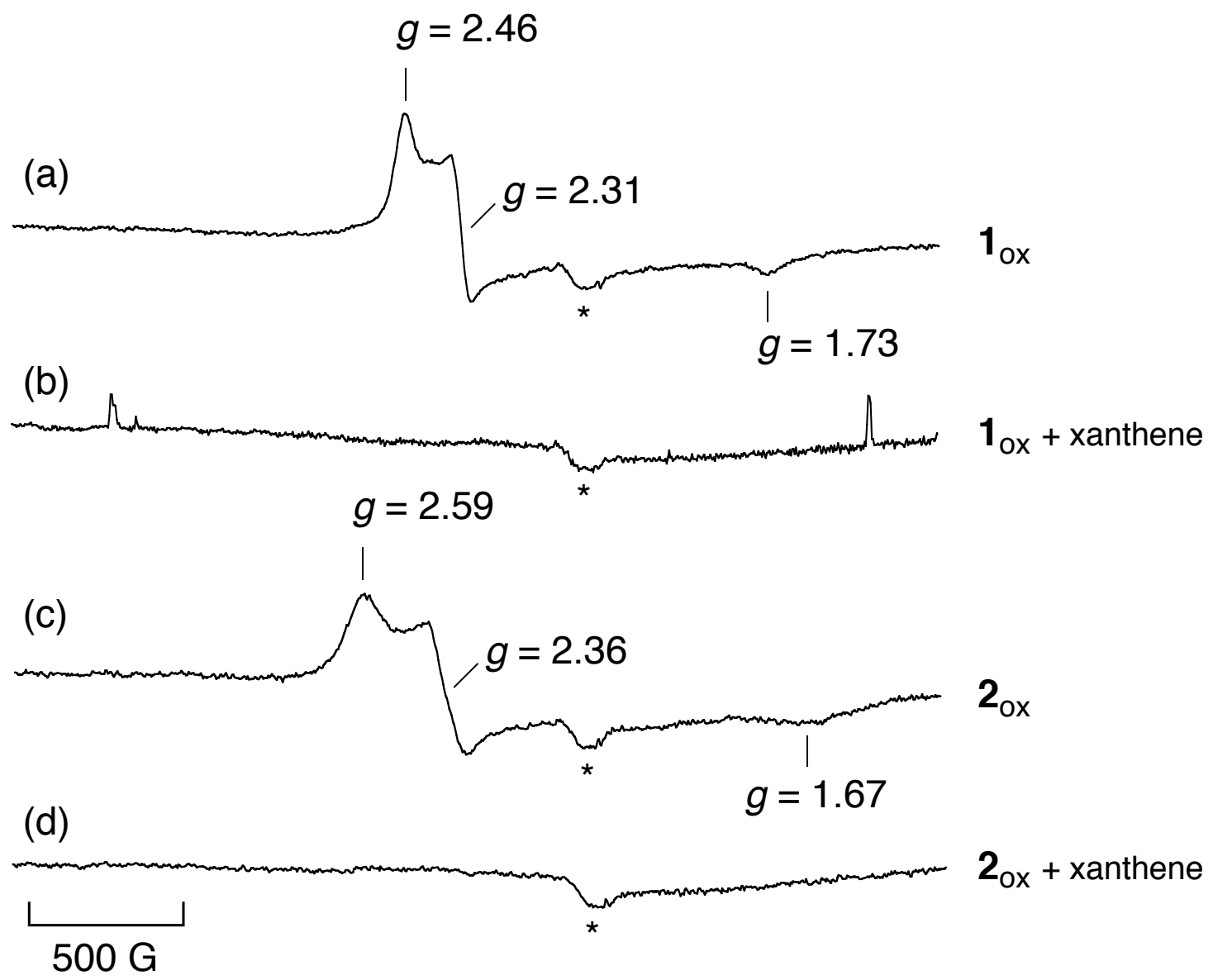

Figure S5. ESR spectra of $\mathbf{1}_{\mathrm{OX}}(0.60 \mathrm{mM})$ (a) and $\boldsymbol{2}_{\mathrm{OX}}(0.49 \mathrm{mM})$ (c) in $\mathrm{MeCN}$ under $\mathrm{Ar}$ atmosphere, and after addition of xanthene $(100 \mathrm{mM})$ to the $\mathrm{MeCN}$ solution of $\mathbf{1}_{\mathrm{OX}}$ (b) and $\boldsymbol{2}_{\mathrm{OX}}(\mathrm{d})$ at room temperature. All ESR spectra were measured at $100 \mathrm{~K}$. ESR spectrometer conditions: Modulation, $100.00 \mathrm{kHz}, 12.0 \mathrm{G}$; gain, $1.00 \times 10^{4}$. Signals with an asterisk are derived from impurities in the ESR cavity.

The spectrum shown in (a) has been reported in ref 33. The anisotropic signals depicted in (a) and (c) are typical for the $\mathrm{Ru}^{\mathrm{III}}$ species $(S=1 / 2)$. See: Pushkar, Y.; Moonshiram, D.; Purohit, V.; Yan, L.; Alperovich, I. J. Am. Chem. Soc. 2014, 136, 11938. 


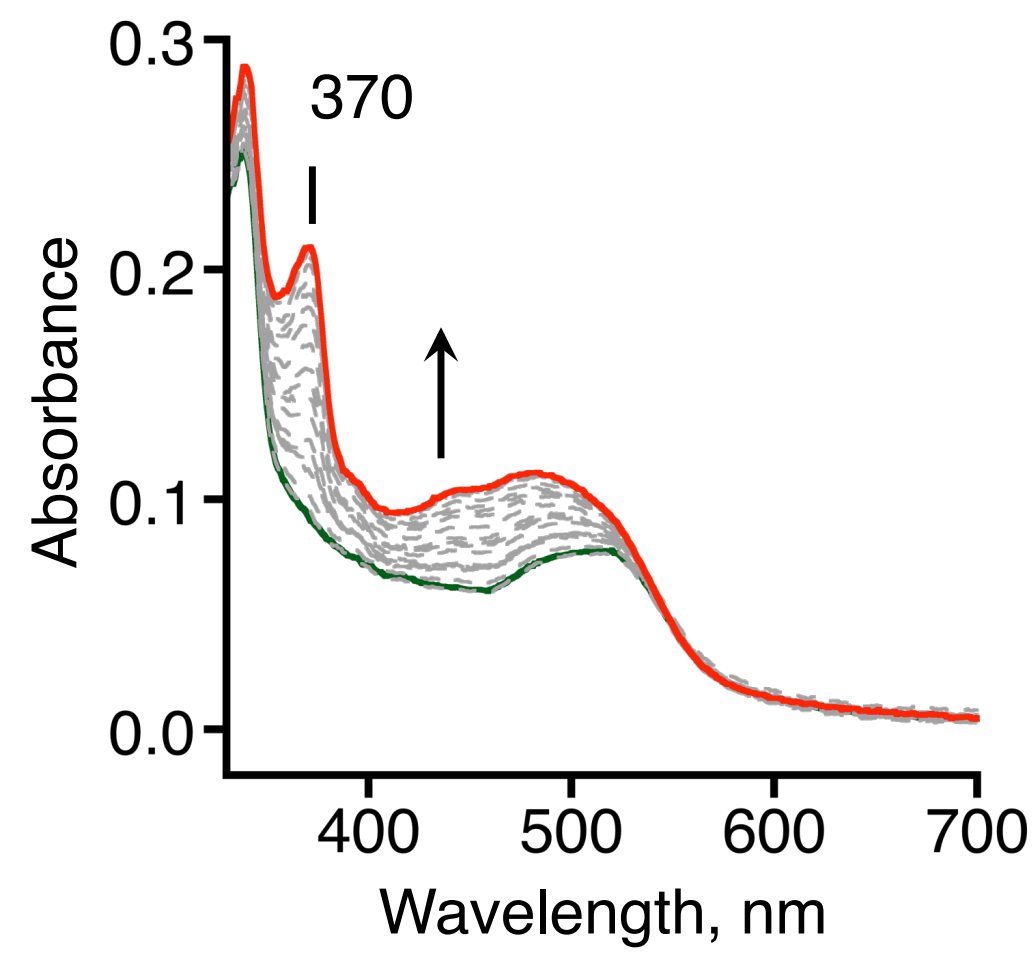

Figure S6. UV-Vis spectral change in the course of oxidation of xanthene with $\mathbf{1}_{\mathrm{OX}}$ at $296 \mathrm{~K}$ in $\mathrm{MeCN} .\left[\mathbf{1}_{\mathrm{OX}}\right]=15 \mu \mathrm{M}$, [xanthene $]=4.2 \mathrm{mM}$. 


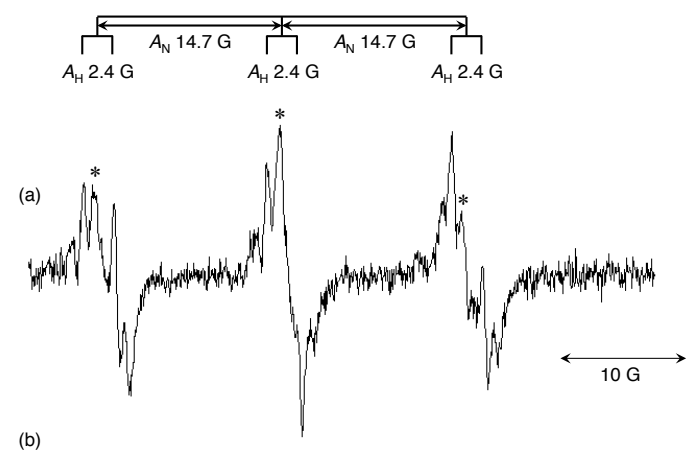

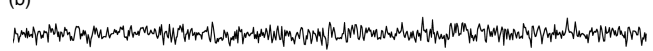

(c)

(c)
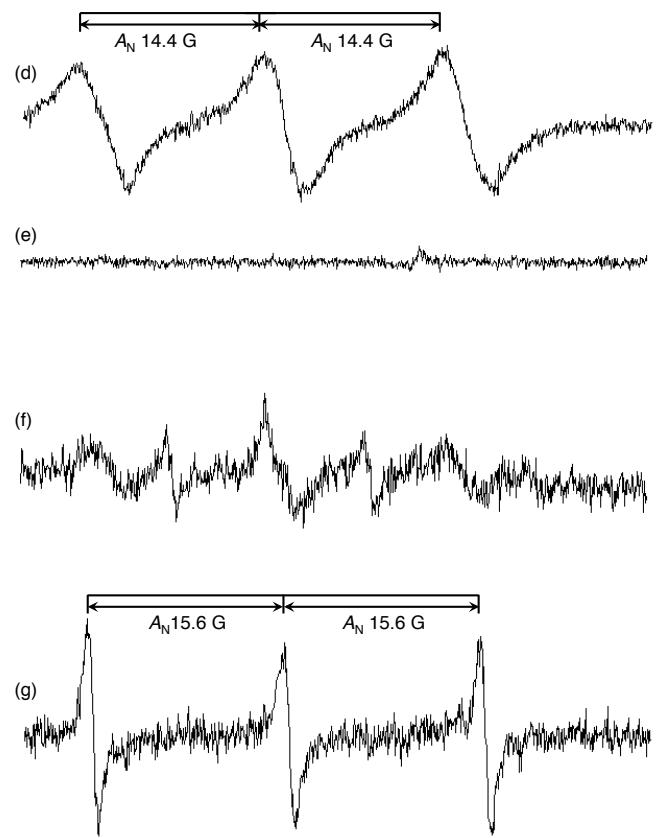

Figure S7. ESR spectra of spin adducts, formed in reactions with the MNP dimer and those of sample solutions, at room temperature under Ar atmosphere. (a) $\mathbf{1}_{\mathrm{OX}}(11 \mu \mathrm{M}) /$ indene $(2.2 \mathrm{mM}) / \mathrm{MNP}$ dimer $(2.2 \mathrm{mM})$ in $\mathrm{MeCN}$ in the dark $(g=2.0064)$, (b) $\mathbf{1}_{\mathrm{OX}}(11$ $\mu \mathrm{M}) / \mathrm{MNP}$ dimer $(2.2 \mathrm{mM})$ in $\mathrm{MeCN}$ in the dark, (c) $\mathbf{1}_{\mathrm{OX}}(11 \mu \mathrm{M}) /$ indene $(2.2 \mathrm{mM})$ in $\mathrm{MeCN}$ in the dark, (d) $\left[\mathrm{Fe}^{\mathrm{III}}(\mathrm{bpy})_{3}\right]^{3+}(11 \mu \mathrm{M}) /$ indene $(2.2 \mathrm{mM}) / \mathrm{MNP} \operatorname{dimer}(2.2 \mathrm{mM})$ in $\mathrm{MeCN}$ in the dark $(g=2.0065)$, (e) $\mathbf{1}_{\mathrm{OX}}(11 \mu \mathrm{M})$ in MeCN in the dark, (f) MNP dimer $(2.2 \mathrm{mM})$ in $\mathrm{MeCN}$ in the dark, $(\mathrm{g}) \mathrm{MNP}$ dimer $(2.2 \mathrm{mM})$ in $\mathrm{MeCN}$ after white-light irradiation $(g=2.0061)$. ESR spectrometer conditions: microwave power, $60 \mathrm{~mW}$; modulation, $100.00 \mathrm{kHz}, 0.50 \mathrm{G}$; scan range, $3510 \pm 25 \mathrm{G}$; gain, $1.00 \times 10^{4}$; scans, 7 . Signals with an asterisk in (a) are those of $\left({ }^{t} \mathrm{Bu}\right)_{2} \mathrm{NO} \cdot$, which is derived from the decomposition of MNP, as depicted in $(\mathrm{g})$ with $A_{\mathrm{N}}=15.6 \mathrm{G}$. 
(a)

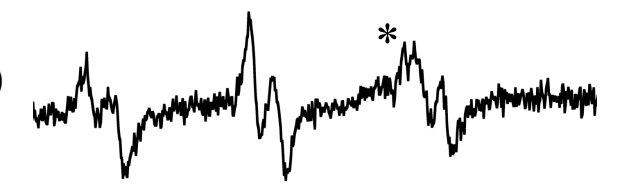

(b)

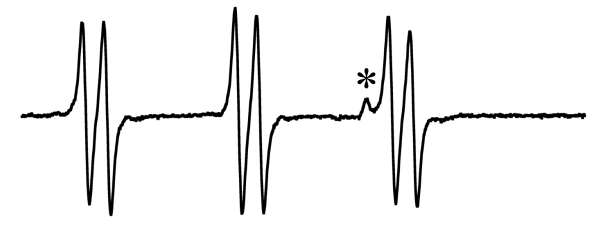

(c)

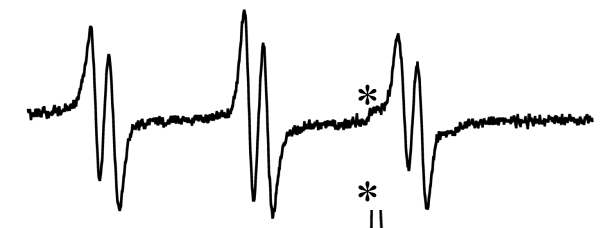

(d)

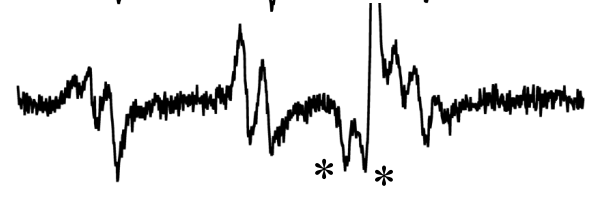

(e)

$20 \mathrm{G}$

Figure S8. ESR spectra of spin adducts formed in reactions with POBN observed at room temperature under Ar atmosphere. (a) $\mathbf{1}_{\mathrm{OX}}(11 \mu \mathrm{M}) /$ fluorene $(2.2 \mathrm{mM}) / \mathrm{POBN}$ $(2.2 \mathrm{mM})$ in $\mathrm{MeCN}(g=2.006)$, (b) $\mathbf{1}_{\mathrm{OX}}(11 \mu \mathrm{M}) / \mathrm{HCp}^{*}(2.2 \mathrm{mM}) / \mathrm{POBN}(2.2 \mathrm{mM})$ in $\operatorname{MeCN}(g=2.012)$, (c) $\mathbf{1}_{\mathrm{OX}}(11 \mu \mathrm{M}) /$ ethylbenzene $(4.4 \mathrm{mM}) / \mathrm{POBN}(2.2 \mathrm{mM})$ in $\operatorname{MeCN}(g=2.006)$, (d) $\mathbf{1}_{\text {Ox }}(11 \mu \mathrm{M}) /$ indene $(1.1 \mathrm{mM}) / \operatorname{POBN}(2.2 \mathrm{mM})$ in $\mathrm{MeCN}(g=$ 2.006), and (e) $\mathbf{1}_{\mathrm{OX}}(11 \mu \mathrm{M}) / \mathrm{POBN}(2.2 \mathrm{mM})$ in MeCN as a control experiment. ESR spectrometer conditions: modulation, $100.00 \mathrm{kHz}, 0.50 \mathrm{G}$; gain, $1.00 \times 10^{4}$. Signals with an asterisk are artifacts. 
(a)

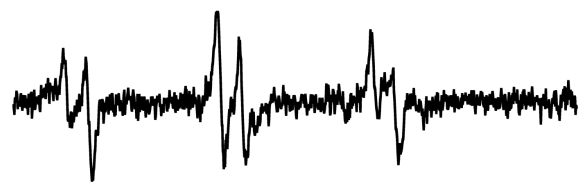

(b)

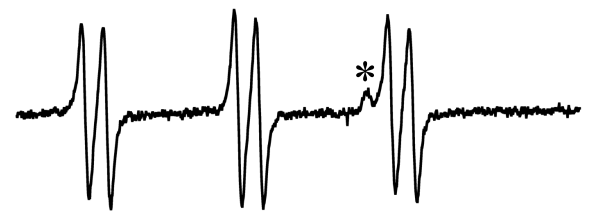

(c)

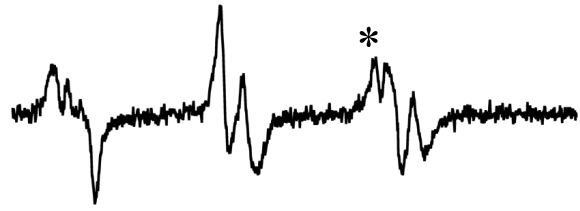

(d)

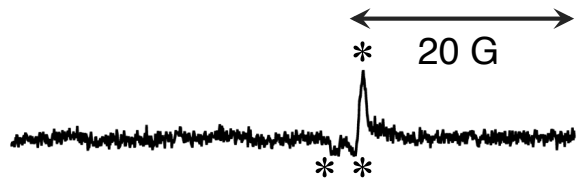

Figure S9. ESR spectra of spin adducts formed in reactions with POBN observed at room temperature under Ar atmosphere. (a) $\mathbf{2}_{\mathrm{OX}}(11 \mu \mathrm{M}) /$ fluorene $(2.2 \mathrm{mM}) / \mathrm{POBN}$ (2.2 $\mathrm{mM})$ in $\mathrm{MeCN}(g=2.006)$, (b) $\mathbf{2}_{\mathrm{OX}}(11 \mu \mathrm{M}) / \mathrm{HCp}^{*}(2.2 \mathrm{mM}) / \mathrm{POBN}(2.2 \mathrm{mM})$ in $\operatorname{MeCN}(g=2.012)$, (c) $\boldsymbol{2}_{\mathrm{OX}}(11 \mu \mathrm{M}) /$ indene $(1.1 \mathrm{mM}) / \operatorname{POBN}(2.2 \mathrm{mM})$ in $\mathrm{MeCN}(g=$ 2.006) and (d) $\boldsymbol{2}_{\mathrm{OX}}(11 \mu \mathrm{M}) / \mathrm{POBN}(2.2 \mathrm{mM})$ in $\mathrm{MeCN}$ as a control experiment. ESR spectrometer conditions: modulation, $100.00 \mathrm{kHz}, 0.50 \mathrm{G}$; gain, $1.00 \times 10^{4}$. Signals with an asterisk are artifacts. 
(a)

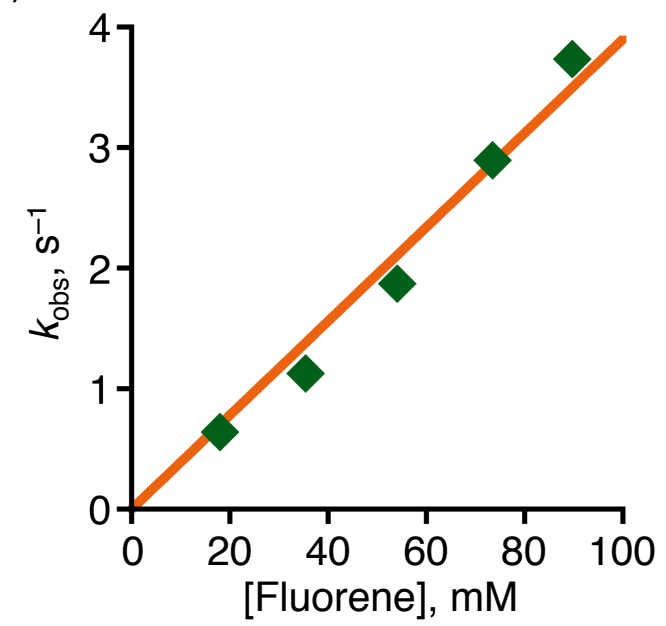

(b)

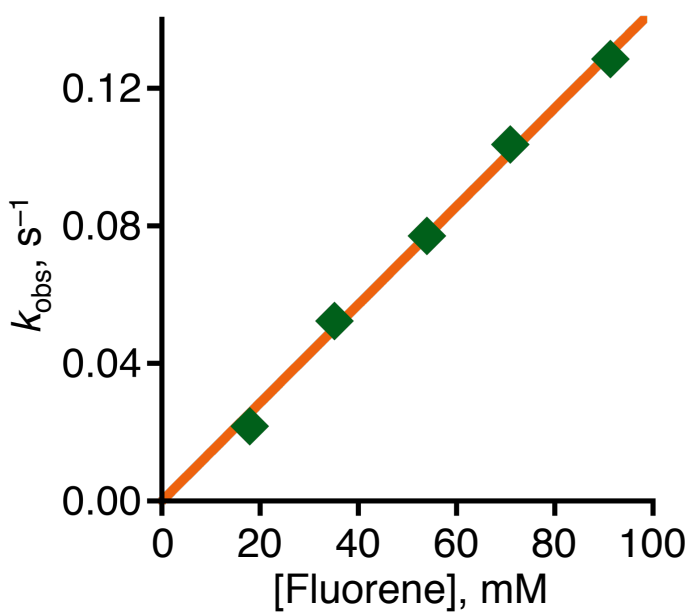

Figure S10. Concentration dependence of $k_{\mathrm{obs}}$ for the oxidation (green squares) of fluorene and the fitting analysis (orange solid line) with $\mathbf{1}_{\mathrm{OX}}$ (a) or $\mathbf{2}_{\mathrm{OX}}$ (b) at $296 \mathrm{~K}$ in $\mathrm{MeCN} .\left[\mathbf{1}_{\mathrm{OX}}\right]_{0}$ or $\left[\mathbf{2}_{\mathrm{OX}}\right]_{0}=15 \mu \mathrm{M}$. 
(a)

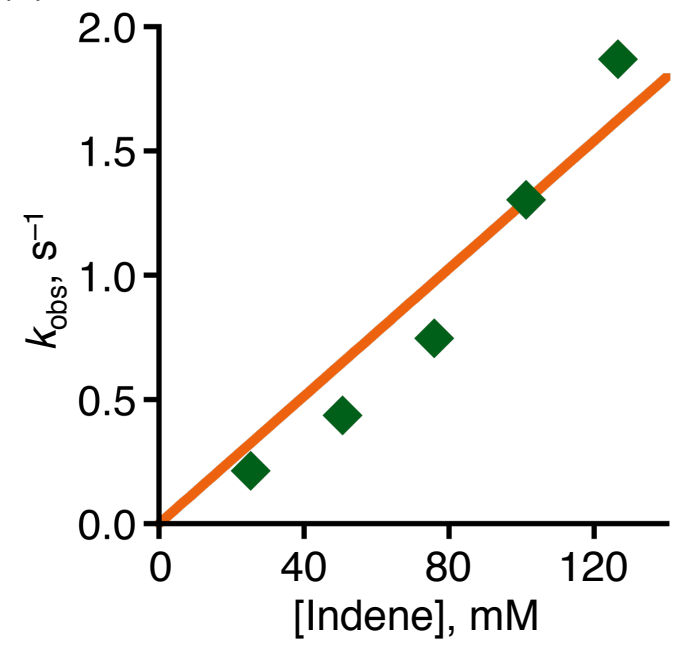

(b)

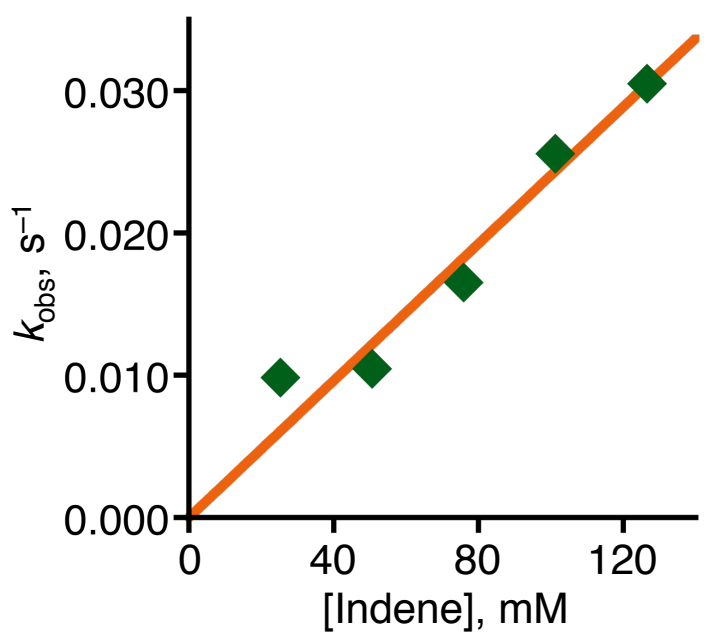

Figure S11. Concentration dependence of $k_{\mathrm{obs}}$ for the oxidation (green squares) of indene and the fitting analysis (orange solid line) with $\mathbf{1}_{\mathrm{OX}}$ (a) or $\mathbf{2}_{\mathrm{OX}}$ (b) at $296 \mathrm{~K}$ in MeCN. [ $\left.\mathbf{1}_{\mathrm{OX}}\right]_{0}$ or $\left[\mathbf{2}_{\mathrm{OX}}\right]_{0}=15 \mu \mathrm{M}$. 
(a)

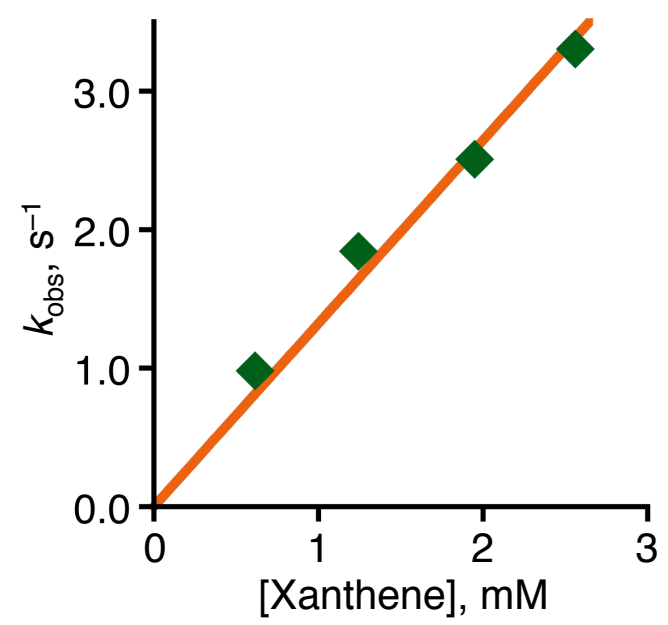

(b)

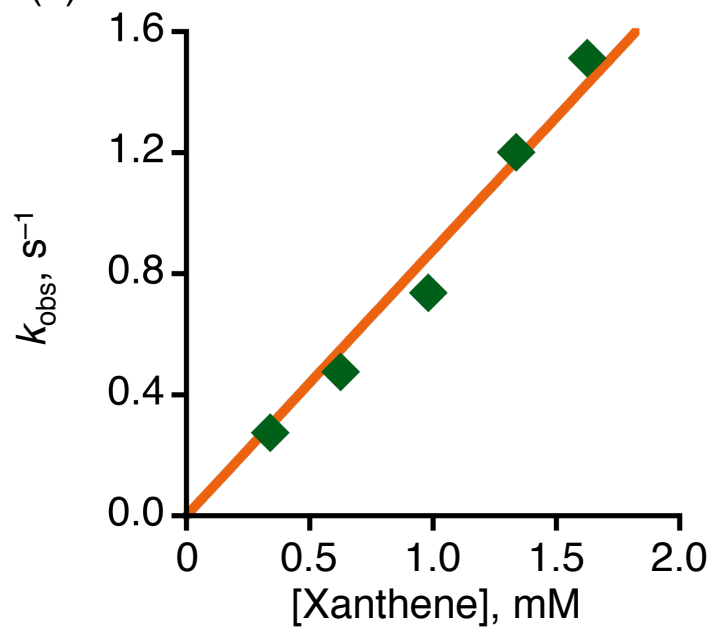

Figure S12. Concentration dependence of $k_{\mathrm{obs}}$ for the oxidation (green squares) of xanthene and the fitting analysis (orange solid line) with $\mathbf{1}_{\mathrm{OX}}$ (a) or $\mathbf{2}_{\mathrm{OX}}$ (b) at $296 \mathrm{~K}$ in $\mathrm{MeCN} .\left[\mathbf{1}_{\mathrm{OX}}\right]_{0}$ or $\left[\mathbf{2}_{\mathrm{OX}}\right]_{0}=15 \mu \mathrm{M}$. 
(a)

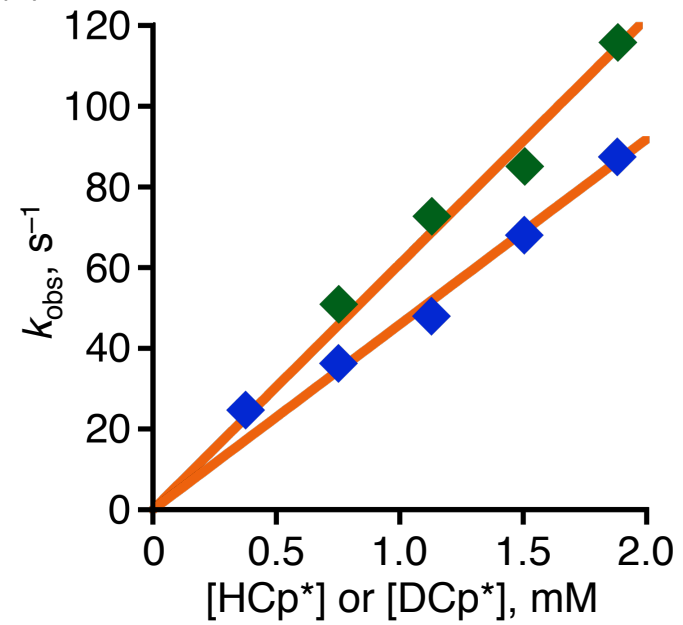

(b)

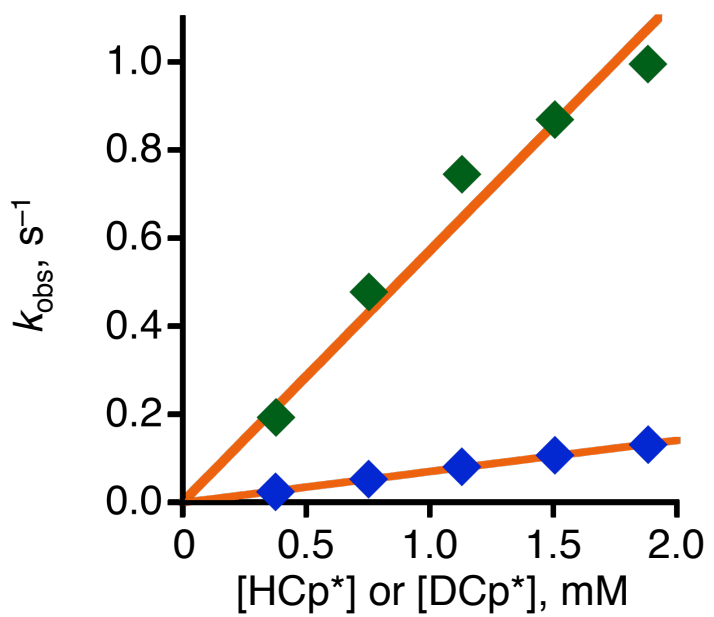

Figure S13. Concentration dependence of $k_{\mathrm{obs}}$ for the oxidation of 1,2,3,4,5-pentamethylcyclopentadiene (green squares for $\mathrm{HCp}^{*}$, blue squares for $\mathrm{DCp}^{*}$ ) and the fitting analysis (orange solid line) with $\mathbf{1}_{\mathrm{OX}}$ (a) or $\mathbf{2}_{\mathrm{OX}}$ (b) at $296 \mathrm{~K}$ in $\mathrm{MeCN}$. $\left[\mathbf{1}_{\mathrm{OX}}\right]_{0}$ or $\left[\mathbf{2}_{\mathrm{OX}}\right]_{0}=15 \mu \mathrm{M}$. 
(a)

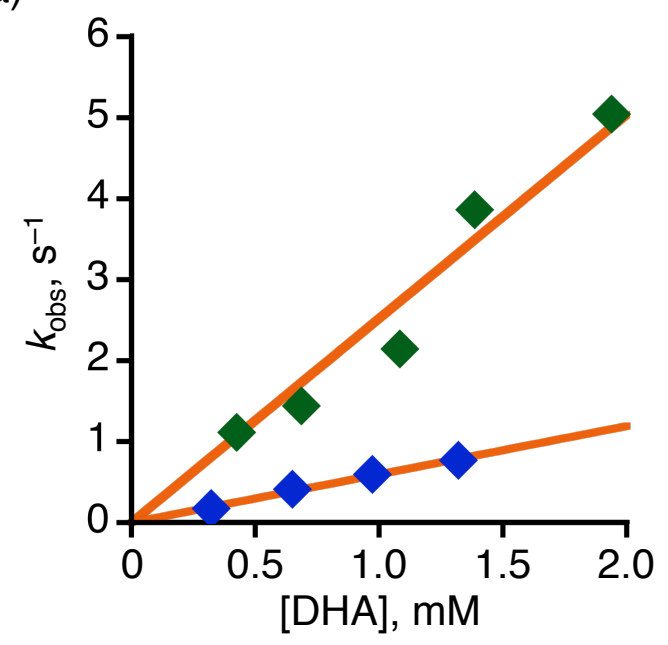

(b)

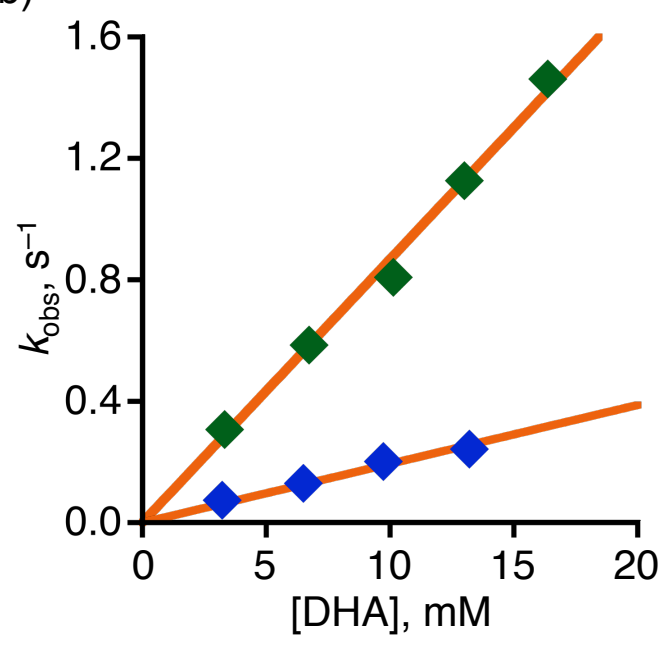

Figure S14. Concentration dependence of $k_{\mathrm{obs}}$ for the oxidation of DHA (green squares, DHA; blue squares, DHA- $d_{4}$ ) and the fitting analysis (orange solid line) with $\mathbf{1}_{\mathrm{OX}}$ (a) or

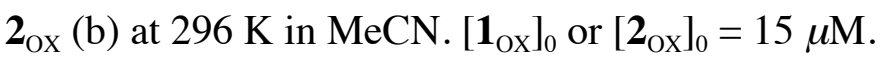




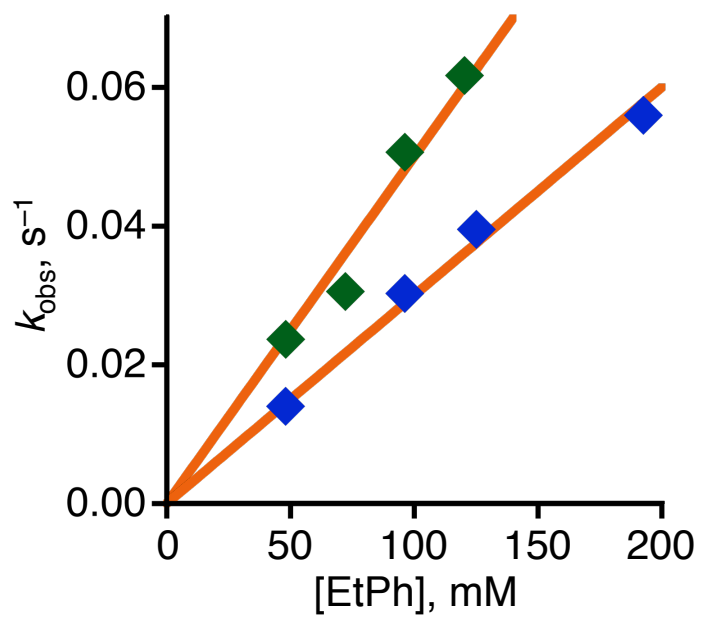

Figure S15. Concentration dependence of $k_{\mathrm{obs}}$ for the oxidation of ethylbenzene (green squares, ethylbenzene; blue squares, ethylbenzene- $d_{10}$ ) and the fitting analysis (orange

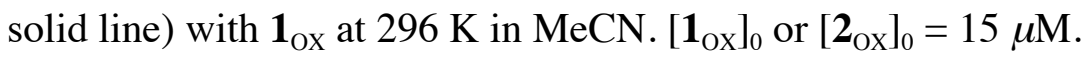


(a)

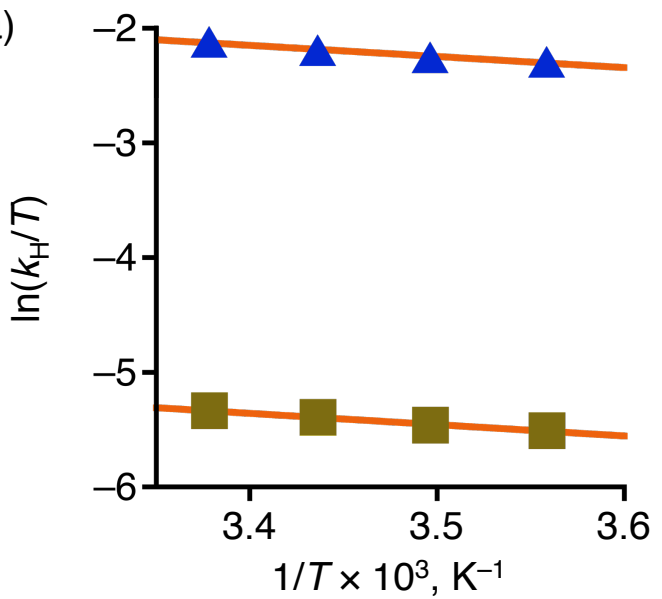

(c)

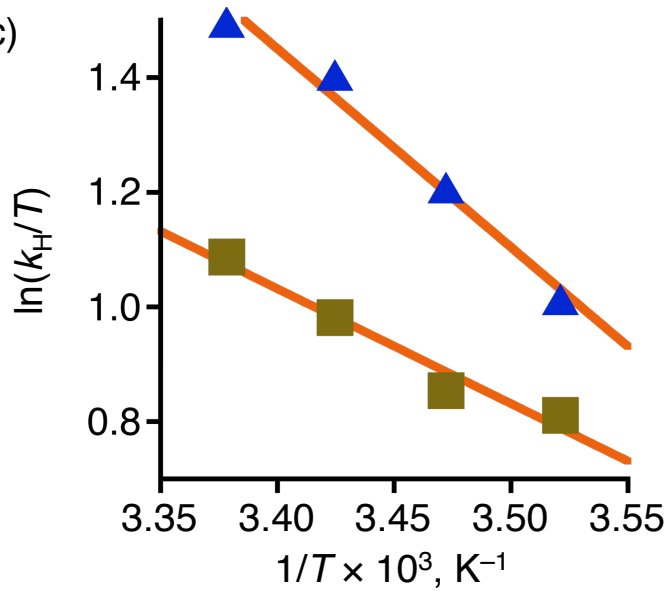

(b)

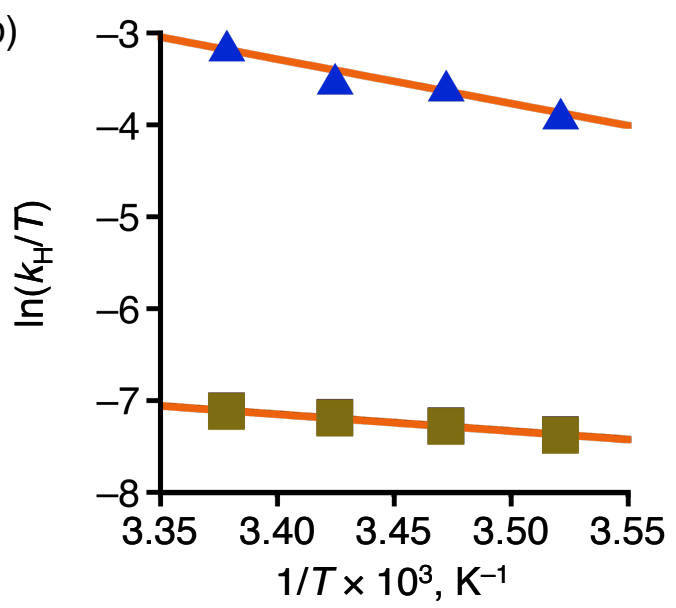

(d)

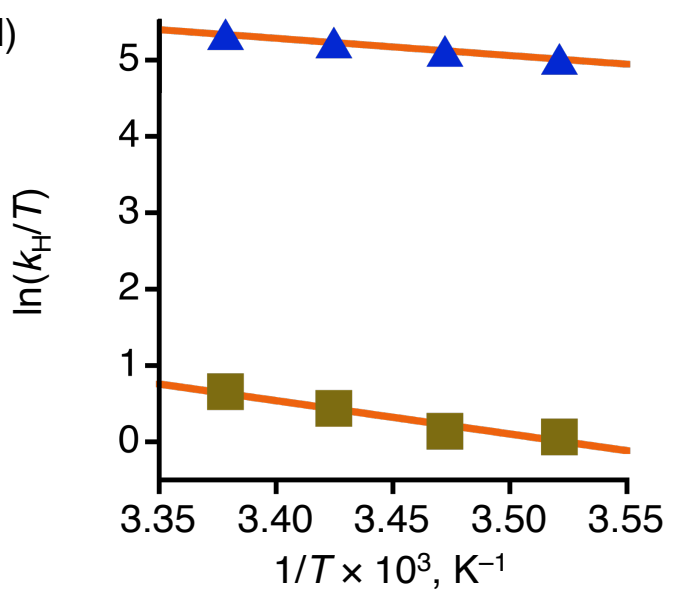

Figure S16. Eyring plots for the oxidation of substrates by $\mathbf{1}_{\mathrm{OX}}$ (blue triangles) and $\mathbf{2}_{\mathrm{OX}}$ (brown squares) in MeCN. (a) fluorene, (b) indene, (c) xanthene and (d) HCp*. 

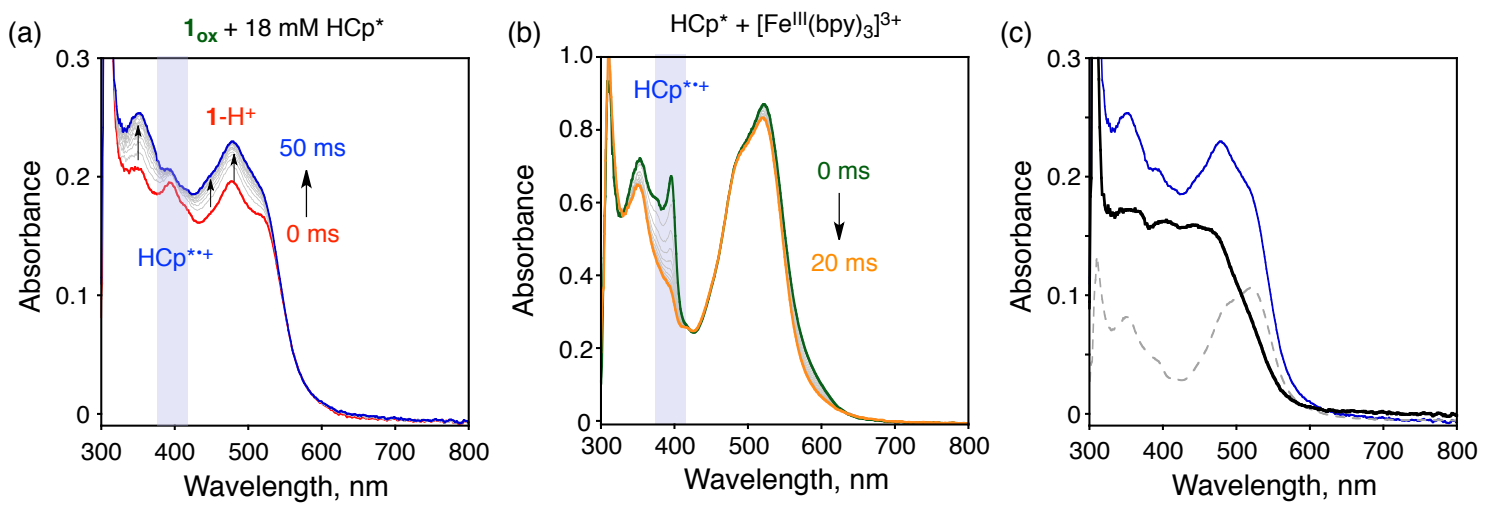

Figure S17. (a) Absorption spectral changes in the course of the oxidation of $\mathrm{HCp}^{*}$ (18 $\mathrm{mM})$ with $\mathbf{1}_{\mathrm{OX}}(16 \mu \mathrm{M})$ in $\mathrm{MeCN}$ at $296 \mathrm{~K}$. (b) Absorption spectral changes in the course of the oxidation of $\mathrm{HCp}^{*}(18 \mathrm{mM})$ by $\left[\mathrm{Fe}^{\mathrm{III}}(\mathrm{bpy})_{3}\right]\left(\mathrm{PF}_{6}\right)_{3}(80 \mu \mathrm{M})$ in $\mathrm{MeCN}$ at 296 K. (c) Difference spectrum (black trace) obtained by subtraction of the spectrum of $\left[\mathrm{Fe}^{\mathrm{II}}(\mathrm{bpy})_{3}\right]^{2+}$ (dotted gray trace) from the final spectrum (blue line) in (a). For the absorption spectrum of $1-\mathrm{H}^{+}$, see SI of the following paper: Miyazaki, S. et al. J. Am. Chem. Soc. 2009, 131, 11615. 


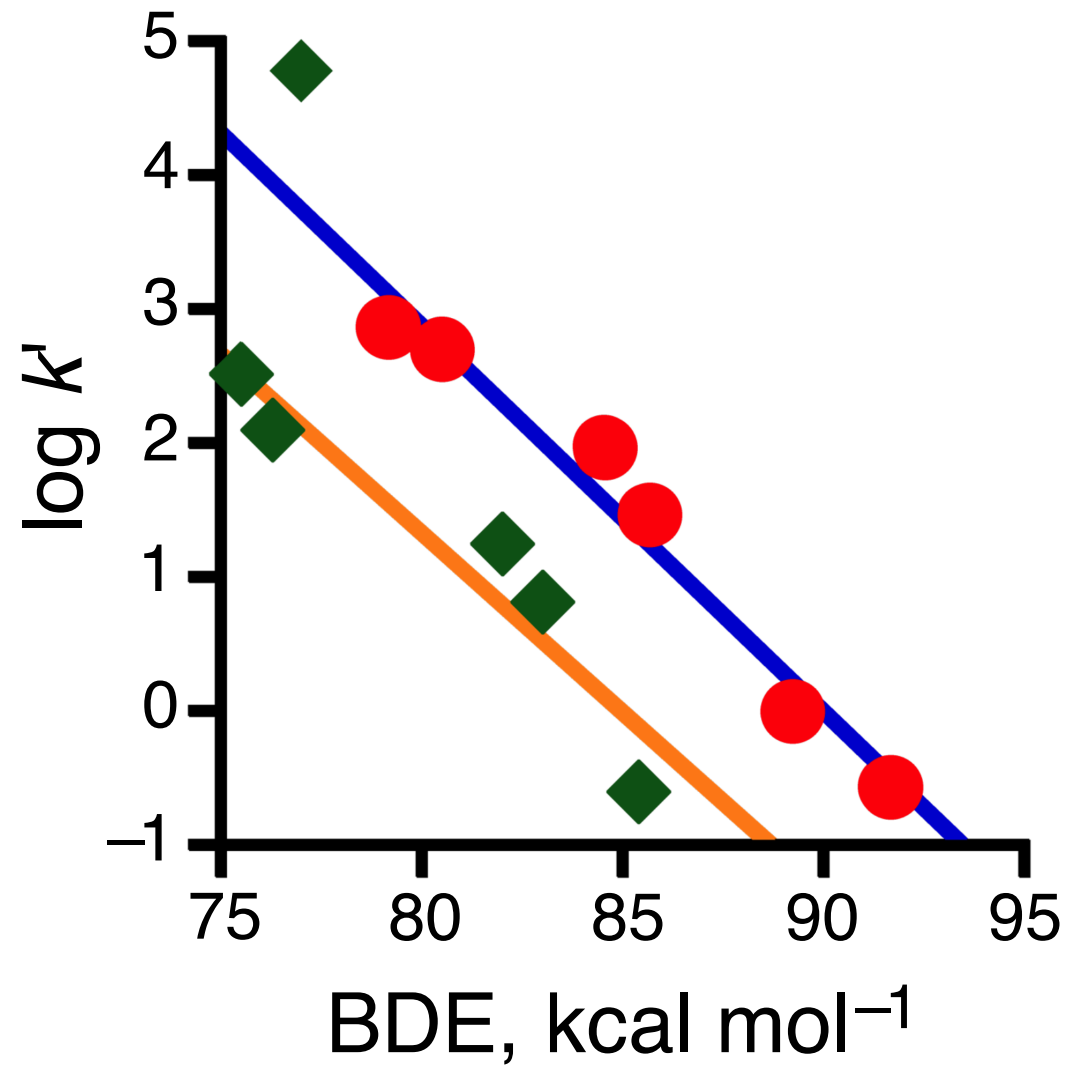

Figure S18. Plots of the $\log k^{\prime}$ values at $296 \mathrm{~K}$ for oxidation of six phenol derivatives and six hydrocarbons with $\mathbf{1}_{\mathrm{Ox}}$ against $\mathrm{BDE}$ values of $\mathrm{O}-\mathrm{H}$ and $\mathrm{C}-\mathrm{H}$ bonds to be cleaved in the substrates: Red circles for the phenol derivatives and green rectangles for hydrocarbons. In the linear fitting for the hydrocarbons, the $k$ ' value for oxidation of $\mathrm{HCp}^{*}$ is not included for the calculations. 
Table S1. Crystallographic Data for 2 and $\left(2-\mathrm{H}^{+}\right) \cdot\left(\mathrm{PF}_{6}\right)$

\begin{tabular}{ccc}
\hline Compound & 2 & $\left(2-\mathrm{H}^{+}\right) \cdot\left(\mathrm{PF}_{6}\right)$ \\
\hline MW & 568.04 & 724.47 \\
Formula & $\mathrm{C}_{23} \mathrm{H}_{27} \mathrm{ClN}_{8} \mathrm{ORu}$ & $\mathrm{C}_{23} \mathrm{H}_{28} \mathrm{ClN}_{8} \mathrm{ORuPF}_{6}$ \\
Crystal system & Monoclinic & Monoclinic \\
Space group & $P 2_{1}$ & $P 2_{1} / c$ \\
$a, \AA$ & $8.702(3)$ & $9.1261(12)$ \\
$b, \AA$ & $12.587(4)$ & $17.015(2)$ \\
$c, \AA$ & $11.310(4)$ & $18.767(2)$ \\
$\alpha,^{\circ}$ & 90 & 90 \\
$\beta,^{\circ}$ & $106.492(4)$ & $96.562(2)$ \\
$\gamma^{\circ}$ & 90 & 90 \\
$V, \AA^{3}$ & $1187.9(7)$ & $2894.9(6)$ \\
$Z$ & 2 & 4.76 \\
$R 1(I>2.00 \sigma(I)), \%$ & 3.98 & 14.56 \\
$w R 2($ all data $), \%$ & 11.24 & 1.201 \\
GOF & 0.850 &
\end{tabular}


Table S2. Cartesian coordinates of $\mathbf{1}_{\mathrm{Ox}}$-reactant $\left(\mathbf{1}_{\mathrm{OX}}+\right.$ indene). Units are in Angstrom.

\begin{tabular}{|c|c|c|c|}
\hline $\mathrm{C}$ & 3.663154 & -1.318512 & -2.416875 \\
\hline $\mathrm{N}$ & 2.817843 & -0.271424 & -2.199419 \\
\hline $\mathrm{C}$ & 2.340417 & 0.404511 & -3.262710 \\
\hline $\mathrm{C}$ & 2.678311 & 0.079487 & -4.578076 \\
\hline $\mathrm{C}$ & 3.551772 & -0.989721 & -4.804905 \\
\hline $\mathrm{C}$ & 4.053216 & -1.694694 & -3.701764 \\
\hline $\mathrm{Ru}$ & 2.427139 & -0.008357 & -0.146016 \\
\hline $\mathrm{N}$ & 3.835396 & 1.555637 & 0.261406 \\
\hline $\mathrm{C}$ & 5.121431 & 1.120838 & 0.343112 \\
\hline $\mathrm{C}$ & 6.161675 & 1.930789 & 0.804021 \\
\hline $\mathrm{C}$ & 5.884674 & 3.240720 & 1.209929 \\
\hline $\mathrm{C}$ & 4.556186 & 3.679461 & 1.166860 \\
\hline $\mathrm{C}$ & 3.573090 & & 0.70030 \\
\hline $\mathrm{C}$ & 5.383476 & -0.286655 & -0.133041 \\
\hline $\mathrm{N}$ & 4.171245 & -1.158735 & -0.008837 \\
\hline $\mathrm{C}$ & 4.095739 & -2.089604 & -1.184260 \\
\hline $\mathrm{N}$ & 0.407815 & 0.806247 & -0.367644 \\
\hline $\mathrm{C}$ & -0.456239 & -0.224817 & -0.148454 \\
\hline $\mathrm{C}$ & -1.866726 & -0.073757 & -0.123685 \\
\hline $\mathrm{N}$ & -2.407018 & 1.169841 & -0.315689 \\
\hline $\mathrm{C}$ & -1.575027 & 2.163033 & -0.586706 \\
\hline $\mathrm{C}$ & -0.139363 & 2.001233 & -0.647124 \\
\hline $\mathrm{C}$ & 0.056256 & -1.572658 & -0.039684 \\
\hline $\mathrm{N}$ & -0.755231 & -2.592376 & 0.154100 \\
\hline $\mathrm{C}$ & -2.099090 & -2.329102 & 0.236796 \\
\hline $\mathrm{N}$ & -2.685926 & -1.116022 & 0.077316 \\
\hline $\mathrm{O}$ & 1.343650 & -1.739105 & -0.188743 \\
\hline $\mathrm{N}$ & -2.907017 & -3.390399 & 0.485049 \\
\hline $\mathrm{C}$ & -2.396538 & -4.752758 & 0.623445 \\
\hline $\mathrm{C}$ & -2.185596 & 3.519692 & -0.843672 \\
\hline $\mathrm{C}$ & 0.724552 & 3.152364 & -1.085978 \\
\hline
\end{tabular}




\begin{tabular}{|c|c|c|c|}
\hline $\mathrm{N}$ & 2.420326 & -0.200023 & 1.939728 \\
\hline $\mathrm{C}$ & 3.372805 & -1.071775 & 2.368781 \\
\hline $\mathrm{C}$ & 3.609700 & -1.284900 & 3.727864 \\
\hline $\mathrm{C}$ & 2.835304 & -0.600967 & 4.674182 \\
\hline $\mathrm{C}$ & 1.846746 & 0.283278 & 4.225740 \\
\hline $\mathrm{C}$ & 1.677778 & 0.458359 & 2.851452 \\
\hline $\mathrm{C}$ & 4.087695 & -1.883776 & 1.302492 \\
\hline $\mathrm{C}$ & -4.356417 & -3.254527 & 0.586747 \\
\hline $\mathrm{C}$ & -6.844284 & 0.513587 & -1.267797 \\
\hline $\mathrm{C}$ & -8.251495 & 0.610432 & -0.719915 \\
\hline $\mathrm{C}$ & -8.177322 & 0.870676 & 0.686292 \\
\hline $\mathrm{C}$ & -6.788494 & 0.944478 & 1.065751 \\
\hline $\mathrm{C}$ & -5.994244 & 0.742694 & -0.042372 \\
\hline $\mathrm{C}$ & -9.350627 & 1.013922 & 1.467857 \\
\hline $\mathrm{C}$ & -10.582231 & 0.894645 & 0.830667 \\
\hline $\mathrm{C}$ & -10.650095 & 0.636919 & -0.561639 \\
\hline $\mathrm{C}$ & -9.482516 & 0.493246 & -1.345610 \\
\hline $\mathrm{H}$ & 1.664608 & 1.225013 & -3.046185 \\
\hline $\mathrm{H}$ & 2.261694 & 0.656481 & -5.398567 \\
\hline $\mathrm{H}$ & 3.839219 & -1.269306 & -5.815461 \\
\hline $\mathrm{H}$ & 4.732890 & -2.531904 & -3.838058 \\
\hline $\mathrm{H}$ & 5.051010 & -2.602769 & -1.352519 \\
\hline $\mathrm{H}$ & 3.326801 & -2.835219 & -0.963114 \\
\hline $\mathrm{H}$ & 6.236974 & -0.726741 & 0.395567 \\
\hline $\mathrm{H}$ & 5.651124 & -0.243086 & -1.194603 \\
\hline $\mathrm{H}$ & 7.173778 & 1.536379 & 0.846756 \\
\hline $\mathrm{H}$ & 6.678875 & 3.891694 & 1.566792 \\
\hline $\mathrm{H}$ & 4.276330 & 4.676729 & 1.494108 \\
\hline $\mathrm{H}$ & 2.535444 & 3.111991 & 0.683678 \\
\hline $\mathrm{H}$ & 3.487117 & -2.782954 & 1.130422 \\
\hline $\mathrm{H}$ & 5.078991 & -2.199032 & 1.649374 \\
\hline $\mathrm{H}$ & 4.381747 & -1.983031 & 4.041014 \\
\hline $\mathrm{H}$ & 3.001442 & -0.756194 & 5.73740 \\
\hline
\end{tabular}




$\begin{array}{lrrr}\mathrm{H} & 1.218639 & 0.832907 & 4.920765 \\ \mathrm{H} & 0.929058 & 1.139240 & 2.457468 \\ \mathrm{H} & 1.743346 & 2.817540 & -1.285386 \\ \mathrm{H} & 0.752010 & 3.962873 & -0.345976 \\ \mathrm{H} & 0.324822 & 3.596737 & -2.004818 \\ \mathrm{H} & -1.706341 & 4.305420 & -0.248664 \\ \mathrm{H} & -3.248511 & 3.486955 & -0.598662 \\ \mathrm{H} & -2.083383 & 3.803892 & -1.899021 \\ \mathrm{H} & -1.319757 & -4.760315 & 0.470597 \\ \mathrm{H} & -2.628342 & -5.139364 & 1.624135 \\ \mathrm{H} & -2.877021 & -5.404200 & -0.117524 \\ \mathrm{H} & -4.628298 & -2.200973 & 0.595657 \\ \mathrm{H} & -4.845095 & -3.750469 & -0.262813 \\ \mathrm{H} & -4.703836 & -3.734339 & 1.509731 \\ \mathrm{H} & -6.634487 & -0.463887 & -1.724835 \\ \mathrm{H} & -6.642613 & 1.265996 & -2.043526 \\ \mathrm{H} & -9.288774 & 1.212673 & 2.535075 \\ \mathrm{H} & -11.504853 & 0.998943 & 1.396146 \\ \mathrm{H} & -11.625613 & 0.548690 & -1.035094 \\ \mathrm{H} & -9.563837 & 0.296619 & -2.412169 \\ \mathrm{H} & -4.906358 & 0.744762 & -0.057006 \\ \mathrm{H} & -6.430197 & 1.132314 & 2.073753\end{array}$


Table S3. Cartesian Coordinates of $\mathbf{1}_{\mathbf{o x}}$-TS. Units are in Angstrom.

\begin{tabular}{|c|c|c|c|}
\hline $\mathrm{C}$ & -6.317700 & 0.731933 & 0.368592 \\
\hline $\mathrm{C}$ & -5.241788 & 0.315094 & 1.327625 \\
\hline $\mathrm{C}$ & -5.866428 & -0.672399 & 2.164429 \\
\hline $\mathrm{C}$ & -7.171409 & -0.959803 & 1.700697 \\
\hline $\mathrm{C}$ & -7.463374 & -0.095447 & 0.603496 \\
\hline $\mathrm{C}$ & -6.353819 & 1.696730 & -0.621043 \\
\hline $\mathrm{C}$ & -7.544596 & 1.841312 & -1.391134 \\
\hline $\mathrm{C}$ & -8.666860 & 1.023498 & -1.175139 \\
\hline $\mathrm{C}$ & -8.640228 & 0.043311 & -0.174377 \\
\hline $\mathrm{N}$ & -3.025531 & -0.810218 & 0.182200 \\
\hline $\mathrm{C}$ & -1.985247 & -0.396130 & 0.965579 \\
\hline $\mathrm{C}$ & -0.701181 & -0.212170 & 0.419744 \\
\hline $\mathrm{C}$ & -0.563408 & -0.315928 & -1.027696 \\
\hline $\mathrm{N}$ & -1.594593 & -0.718107 & \\
\hline $\mathrm{C}$ & -2.763296 & -1.014720 & -1.147849 \\
\hline $\mathrm{N}$ & -2.214060 & -0.164030 & 2.281793 \\
\hline $\mathrm{C}$ & -1.190444 & 0.279184 & 3.005848 \\
\hline $\mathrm{C}$ & 0.125951 & 0.475710 & 2.459164 \\
\hline $\mathrm{N}$ & 0.371906 & 0.177413 & 1.168810 \\
\hline Ru & 2.108310 & 0.192796 & -0.139680 \\
\hline $\mathrm{N}$ & 2.355722 & -1.877968 & -0.318280 \\
\hline $\mathrm{C}$ & 3.109762 & -2.208960 & -1.401446 \\
\hline $\mathrm{C}$ & 3.492582 & -3.527272 & -1.655756 \\
\hline $\mathrm{C}$ & 3.075890 & -4.543198 & -0.785901 \\
\hline $\mathrm{C}$ & 2.289393 & -4.199996 & 0.320142 \\
\hline $\mathrm{C}$ & 1.960467 & -2.857773 & 0.518731 \\
\hline $\mathrm{C}$ & -1.460396 & 0.576691 & 4.459434 \\
\hline $\mathrm{C}$ & 1.203879 & 1.080393 & 3.316926 \\
\hline $\mathrm{N}$ & -3.741197 & -1.564118 & -1.904933 \\
\hline $\mathrm{C}$ & -4.955141 & -2.131495 & -1.326392 \\
\hline $\mathrm{O}$ & 0.562344 & 0.021165 & -1.545 \\
\hline
\end{tabular}




\begin{tabular}{|c|c|c|c|}
\hline $\mathrm{C}$ & 3.425114 & -1.089481 & -2.376900 \\
\hline $\mathrm{N}$ & 3.498370 & 0.247799 & -1.703927 \\
\hline $\mathrm{C}$ & 4.861389 & 0.577768 & -1.174834 \\
\hline C & 5.037860 & 0.120318 & 0.251721 \\
\hline $\mathrm{N}$ & 3.906137 & 0.044341 & 1.002638 \\
\hline $\mathrm{C}$ & 4.040935 & -0.392783 & 2.274955 \\
\hline $\mathrm{C}$ & 5.269462 & -0.699344 & 2.860398 \\
\hline $\mathrm{C}$ & 6.434389 & -0.575629 & 2.095155 \\
\hline $\mathrm{C}$ & 6.304558 & -0.174389 & 0.761489 \\
\hline $\mathrm{N}$ & 2.138492 & 2.273810 & -0.505708 \\
\hline $\mathrm{C}$ & 1.728920 & 3.299130 & 0.266549 \\
\hline $\mathrm{C}$ & 1.792874 & 4.632927 & -0.143792 \\
\hline $\mathrm{C}$ & 2.310973 & 4.925000 & -1.409837 \\
\hline $\mathrm{C}$ & 2.744396 & 3.863861 & -2.216568 \\
\hline $\mathrm{C}$ & 2.638029 & 2.556565 & -1.741783 \\
\hline $\mathrm{C}$ & 3.019314 & 1.358799 & -2.590802 \\
\hline $\mathrm{C}$ & -3.599158 & -1.705542 & -3.356270 \\
\hline $\mathrm{H}$ & 1.336284 & 3.037515 & 1.243454 \\
\hline $\mathrm{H}$ & 1.446443 & 5.417586 & 0.522725 \\
\hline $\mathrm{H}$ & 2.381972 & 5.951467 & -1.760844 \\
\hline $\mathrm{H}$ & 3.155898 & 4.048266 & -3.205664 \\
\hline $\mathrm{H}$ & 3.774306 & 1.629724 & -3.340055 \\
\hline $\mathrm{H}$ & 2.121951 & 1.004073 & -3.105319 \\
\hline $\mathrm{H}$ & 5.643777 & 0.161764 & -1.820430 \\
\hline $\mathrm{H}$ & 4.968356 & 1.667746 & -1.200680 \\
\hline $\mathrm{H}$ & 7.176051 & -0.093452 & 0.116711 \\
\hline $\mathrm{H}$ & 7.410342 & -0.804034 & 2.515816 \\
\hline $\mathrm{H}$ & 5.300689 & -1.035547 & 3.892907 \\
\hline $\mathrm{H}$ & 3.125794 & -0.512410 & 2.838710 \\
\hline $\mathrm{H}$ & 2.595377 & -1.041786 & -3.089794 \\
\hline $\mathrm{H}$ & 4.341267 & -1.306659 & -2.939476 \\
\hline $\mathrm{H}$ & 4.102189 & -3.756060 & -2.526190 \\
\hline $\mathrm{H}$ & 3.360956 & -5.576488 & -0.967621 \\
\hline
\end{tabular}




$\begin{array}{lrrr}\mathrm{H} & 1.940035 & -4.950465 & 1.023423 \\ \mathrm{H} & 1.361829 & -2.546267 & 1.369817 \\ \mathrm{H} & 2.067570 & 1.353793 & 2.711212 \\ \mathrm{H} & 1.525887 & 0.405317 & 4.119835 \\ \mathrm{H} & 0.830038 & 1.983978 & 3.812243 \\ \mathrm{H} & -0.728573 & 0.094065 & 5.116895 \\ \mathrm{H} & -2.459334 & 0.224386 & 4.721695 \\ \mathrm{H} & -1.410452 & 1.655273 & 4.657636 \\ \mathrm{H} & -2.780988 & -1.080467 & -3.708705 \\ \mathrm{H} & -3.389694 & -2.749940 & -3.620698 \\ \mathrm{H} & -4.535593 & -1.402875 & -3.837357 \\ \mathrm{H} & -4.792402 & -2.392727 & -0.279031 \\ \mathrm{H} & -5.799900 & -1.434953 & -1.397045 \\ \mathrm{H} & -5.212358 & -3.040538 & -1.879486 \\ \mathrm{H} & -4.289204 & -0.329367 & 0.732698 \\ \mathrm{H} & -4.601513 & 1.065762 & 1.797134 \\ \mathrm{H} & -9.510281 & -0.580944 & 0.017313 \\ \mathrm{H} & -9.558861 & 1.163855 & -1.779912 \\ \mathrm{H} & -7.585431 & 2.605030 & -2.164947 \\ \mathrm{H} & -5.502173 & 2.344114 & -0.818868 \\ \mathrm{H} & -5.386295 & -1.150866 & 3.012722 \\ \mathrm{H} & -7.845048 & -1.697237 & 2.127853\end{array}$


Table S4. Cartesian Coordinates of $\mathbf{2}_{\mathrm{ox}}$-reactant $\left(\mathbf{2}_{\mathrm{OX}}+\right.$ indene). Units are in Angstrom.

\begin{tabular}{|c|c|c|c|}
\hline $\mathrm{C}$ & -3.502454 & -2.428025 & 1.050449 \\
\hline $\mathrm{N}$ & -3.276448 & -1.567320 & 0.032163 \\
\hline $\mathrm{C}$ & -4.102195 & -1.603928 & -1.045455 \\
\hline $\mathrm{C}$ & -5.173993 & -2.496141 & -1.128526 \\
\hline $\mathrm{C}$ & -5.400658 & -3.394533 & -0.078945 \\
\hline $\mathrm{C}$ & -4.542225 & -3.358780 & 1.026742 \\
\hline $\mathrm{Ru}$ & -1.976264 & 0.065500 & 0.083718 \\
\hline $\mathrm{N}$ & -2.957196 & 0.512510 & -1.804496 \\
\hline $\mathrm{C}$ & -3.733251 & -0.704364 & -2.204727 \\
\hline $\mathrm{N}$ & -0.076996 & -0.692098 & -0.572778 \\
\hline $\mathrm{C}$ & 0.825672 & 0.322766 & -0.495285 \\
\hline $\mathrm{C}$ & 2.203532 & 0.120590 & -0.652786 \\
\hline $\mathrm{N}$ & 2.704191 & -1.118435 & -0.848298 \\
\hline $\mathrm{C}$ & 1.829719 & -2.118212 & -0.923438 \\
\hline $\mathrm{C}$ & 0.409358 & -1.922092 & -0.806388 \\
\hline $\mathrm{N}$ & 3.071537 & 1.181877 & -0.585148 \\
\hline $\mathrm{C}$ & 2.521009 & 2.430164 & -0.420762 \\
\hline $\mathrm{N}$ & 1.210231 & 2.695995 & -0.249302 \\
\hline $\mathrm{C}$ & 0.353757 & 1.671398 & -0.228289 \\
\hline $\mathrm{N}$ & 3.374863 & 3.487652 & -0.429335 \\
\hline $\mathrm{C}$ & 2.885869 & 4.840138 & -0.161161 \\
\hline $\mathrm{O}$ & -0.902364 & 1.832642 & -0.027112 \\
\hline $\mathrm{C}$ & -0.544643 & -3.079641 & -0.895314 \\
\hline $\mathrm{C}$ & 2.405479 & -3.498751 & -1.127762 \\
\hline $\mathrm{Cl}$ & -1.100694 & -0.454180 & 2.276698 \\
\hline $\mathrm{N}$ & -3.639806 & 1.082279 & 0.812079 \\
\hline $\mathrm{C}$ & -4.017101 & 1.144702 & 2.106272 \\
\hline $\mathrm{C}$ & -5.190047 & 1.787367 & 2.507213 \\
\hline $\mathrm{C}$ & -6.013257 & 2.371483 & 1.537187 \\
\hline $\mathrm{C}$ & -5.619171 & 2.305475 & 0.195150 \\
\hline $\mathrm{C}$ & -4.421697 & 1.664049 & -0.128849 \\
\hline
\end{tabular}




\begin{tabular}{|c|c|c|c|}
\hline $\mathrm{C}$ & -3.848018 & 1.684356 & -1.523369 \\
\hline $\mathrm{C}$ & 4.732785 & 3.400880 & -0.960731 \\
\hline $\mathrm{C}$ & -2.039483 & 0.889177 & -2.916061 \\
\hline $\mathrm{C}$ & 5.575687 & 0.539565 & 1.774231 \\
\hline $\mathrm{C}$ & 6.650502 & -0.299693 & 1.169342 \\
\hline $\mathrm{C}$ & 6.517814 & -1.619195 & 1.690960 \\
\hline $\mathrm{C}$ & 5.436949 & -1.610903 & 2.655939 \\
\hline $\mathrm{C}$ & 4.916140 & -0.323131 & 2.735342 \\
\hline $\mathrm{C}$ & 7.377439 & -2.646944 & 1.274533 \\
\hline $\mathrm{C}$ & 8.381305 & -2.348873 & 0.331136 \\
\hline $\mathrm{C}$ & 8.513948 & -1.050426 & -0.175899 \\
\hline $\mathrm{C}$ & 7.641403 & -0.012225 & 0.238525 \\
\hline $\mathrm{H}$ & 4.917879 & 2.405144 & -1.362828 \\
\hline $\mathrm{H}$ & 5.475059 & 3.625279 & -0.184181 \\
\hline $\mathrm{H}$ & 4.853038 & 4.135055 & -1.767814 \\
\hline $\mathrm{H}$ & 3.686035 & 5.411571 & 0.320859 \\
\hline $\mathrm{H}$ & 2.015890 & 4.799425 & 0.493000 \\
\hline $\mathrm{H}$ & 2.599298 & 5.348796 & -1.091836 \\
\hline $\mathrm{H}$ & 2.059571 & -4.196948 & -0.356719 \\
\hline $\mathrm{H}$ & 3.494194 & -3.433374 & -1.089928 \\
\hline $\mathrm{H}$ & 2.114625 & -3.912542 & -2.101583 \\
\hline $\mathrm{H}$ & -1.475538 & -2.772112 & -1.375102 \\
\hline $\mathrm{H}$ & -0.797061 & -3.440166 & 0.109790 \\
\hline $\mathrm{H}$ & -0.117122 & -3.911932 & -1.457145 \\
\hline $\mathrm{H}$ & -4.626307 & -0.428037 & -2.780545 \\
\hline $\mathrm{H}$ & -3.089345 & -1.283584 & -2.877234 \\
\hline $\mathrm{H}$ & -5.816091 & -2.488608 & -2.005870 \\
\hline $\mathrm{H}$ & -6.227416 & -4.099224 & -0.122629 \\
\hline $\mathrm{H}$ & -4.674791 & -4.029743 & 1.870840 \\
\hline $\mathrm{H}$ & -2.821848 & -2.335879 & 1.892604 \\
\hline $\mathrm{H}$ & -4.638633 & 1.771138 & -2.280996 \\
\hline $\mathrm{H}$ & -3.214948 & 2.575712 & -1.596089 \\
\hline $\mathrm{H}$ & -6.222183 & 2.756003 & -0.589089 \\
\hline
\end{tabular}




$\begin{array}{lrrr}\mathrm{H} & -6.937895 & 2.870351 & 1.817357 \\ \mathrm{H} & -5.444915 & 1.819380 & 3.562661 \\ \mathrm{H} & -3.340144 & 0.672427 & 2.812790 \\ \mathrm{H} & -1.449958 & 1.755010 & -2.609402 \\ \mathrm{H} & -2.602219 & 1.135073 & -3.828338 \\ \mathrm{H} & -1.362750 & 0.057521 & -3.122878 \\ \mathrm{H} & 4.835581 & 0.705511 & 0.977547 \\ \mathrm{H} & 5.104342 & -2.466112 & 3.237078 \\ \mathrm{H} & 5.759385 & 1.586936 & 2.026464 \\ \mathrm{H} & 7.288722 & -3.650886 & 1.685224 \\ \mathrm{H} & 9.064581 & -3.127899 & 0.001000 \\ \mathrm{H} & 9.299434 & -0.833619 & -0.896601 \\ \mathrm{H} & 7.763891 & 0.989390 & -0.169538 \\ \mathrm{H} & 4.112306 & -0.010941 & 3.395452\end{array}$


Table S5. Cartesian Coordinates of $\mathbf{2}_{\mathbf{O x}}$-TS. Units are in Angstrom.

\begin{tabular}{|c|c|c|c|}
\hline $\mathrm{C}$ & 6.076434 & -0.152447 & 0.628461 \\
\hline $\mathrm{C}$ & 5.001619 & 0.686812 & 123235 \\
\hline $\mathrm{C}$ & 4.342072 & -0.175884 & 2.194462 \\
\hline $\mathrm{C}$ & 4.862881 & -1.463656 & 2.11505 \\
\hline $\mathrm{C}$ & 5.943746 & -1.471949 & 1.15008 \\
\hline $\mathrm{C}$ & 7.067335 & 0.135021 & -0.30235 \\
\hline $\mathrm{C}$ & 7.939880 & -0.903180 & O 716780 \\
\hline $\mathrm{C}$ & 7.807237 & -2.201627 & -0.209745 \\
\hline $\mathrm{C}$ & 6.803371 & -2.499698 & \\
\hline $\mathrm{N}$ & 3.071537 & 1.181876 & -0.58514 \\
\hline C & 2.521010 & 2.430163 & -0.420762 \\
\hline $\mathrm{N}$ & 1.210232 & 2.695994 & -0.24930 \\
\hline $\mathrm{C}$ & 0.353757 & 1.671398 & \\
\hline $\mathrm{C}$ & 0.825672 & 0.322765 & -0.49528 \\
\hline C & 2.203532 & 0.120589 & -0.652786 \\
\hline $\mathrm{N}$ & -0.076996 & -0.692098 & -0.572778 \\
\hline $\mathrm{C}$ & 0.409358 & -1.922092 & -0.806388 \\
\hline $\mathrm{C}$ & 1.829719 & -2.118213 & -0.923438 \\
\hline $\mathrm{N}$ & 2.704191 & -1.118436 & -0.848298 \\
\hline $\mathrm{O}$ & -0.902364 & 1.832642 & -0.027112 \\
\hline $\mathrm{Ru}$ & -1.976264 & 0.065500 & 0.083718 \\
\hline $\mathrm{Cl}$ & -1.100694 & -0.454180 & 2.276698 \\
\hline $\mathrm{N}$ & 3.374864 & 3.487651 & -0.42933 \\
\hline $\mathrm{C}$ & 4.732786 & 3.400879 & -0.960732 \\
\hline $\mathrm{C}$ & 2.405479 & -3.498752 & -1.127762 \\
\hline $\mathrm{C}$ & -0.544643 & -3.079642 & -0.895314 \\
\hline $\mathrm{N}$ & -3.639806 & 1.082279 & 0.81207 \\
\hline $\mathrm{C}$ & -4.017101 & 1.144703 & 2.10627 \\
\hline $\mathrm{C}$ & -5.190046 & 1.787368 & 2.5072 \\
\hline $\mathrm{C}$ & -6.013256 & 2.371484 & 1.53718 \\
\hline $\mathrm{C}$ & -5.619170 & 2.305476 & 0.195 \\
\hline
\end{tabular}




\begin{tabular}{|c|c|c|c|}
\hline $\mathrm{C}$ & -4.421696 & 1.664049 & -0.128849 \\
\hline $\mathrm{C}$ & -3.848017 & 1.684356 & -1.523369 \\
\hline & -2.957196 & 0.512510 & -1.804496 \\
\hline $\mathrm{C}$ & -2.039483 & 0.889177 & -2.916061 \\
\hline $\mathrm{N}$ & -3.276448 & -1.567320 & 0.032163 \\
\hline $\mathrm{C}$ & -4.102195 & -1.603928 & -1.045455 \\
\hline $\mathrm{C}$ & -5.173993 & -2.496141 & -1.128526 \\
\hline $\mathrm{C}$ & -5.400658 & -3.394533 & \\
\hline $\mathrm{C}$ & -4.542225 & -3.358780 & 1.026742 \\
\hline $\mathrm{C}$ & -3.502454 & -2.428025 & 1.050449 \\
\hline $\mathrm{C}$ & -3.733251 & -0.704364 & -2.204727 \\
\hline $\mathrm{C}$ & 2.885870 & 4.840137 & \\
\hline $\mathrm{H}$ & 4.917879 & 2.405143 & -1.362829 \\
\hline $\mathrm{H}$ & 5.475060 & 3.625278 & -0.184182 \\
\hline $\mathrm{H}$ & 4.853039 & 4.135054 & -1.767815 \\
\hline $\mathrm{H}$ & 3.686036 & 5.411570 & 0.320858 \\
\hline $\mathrm{H}$ & 2.015891 & 4.799425 & 0.493000 \\
\hline $\mathrm{H}$ & 2.599299 & 5.348795 & 1837 \\
\hline $\mathrm{H}$ & 2.059571 & -4.196949 & -0.356719 \\
\hline $\mathrm{H}$ & 3.494194 & -3.433375 & -1.089928 \\
\hline $\mathrm{H}$ & 2.114625 & -3.912543 & -2.101583 \\
\hline $\mathrm{H}$ & -1.475538 & -2.772113 & -1.375102 \\
\hline $\mathrm{H}$ & -0.797061 & -3.440166 & 0.109790 \\
\hline $\mathrm{H}$ & -0.117122 & -3.911933 & -1.457145 \\
\hline $\mathrm{H}$ & -4.626307 & -0.428037 & -2.780545 \\
\hline $\mathrm{H}$ & -3.089345 & -1.283584 & \\
\hline $\mathrm{H}$ & -5.816091 & -2.488608 & -2.005870 \\
\hline $\mathrm{H}$ & -6.227416 & -4.099224 & -0.122629 \\
\hline $\mathrm{H}$ & -4.674791 & -4.029743 & 1.870840 \\
\hline $\mathrm{H}$ & -2.821848 & -2.335879 & 1.892604 \\
\hline $\mathrm{H}$ & -4.638632 & 1.771138 & -2.280996 \\
\hline $\mathrm{H}$ & -3.214947 & 2.575712 & -1.596089 \\
\hline 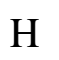 & -6.222182 & 2.756004 & -0.58908 \\
\hline
\end{tabular}




$\begin{array}{lrrr}\mathrm{H} & -6.937894 & 2.870352 & 1.817357 \\ \mathrm{H} & -5.444914 & 1.819381 & 3.562661 \\ \mathrm{H} & -3.340144 & 0.672427 & 2.812790 \\ \mathrm{H} & -1.449958 & 1.755010 & -2.609402 \\ \mathrm{H} & -2.602219 & 1.135073 & -3.828338 \\ \mathrm{H} & -1.362750 & 0.057521 & -3.122878 \\ \mathrm{H} & 4.101635 & 0.888606 & 0.264567 \\ \mathrm{H} & 4.530274 & -2.318865 & 2.696198 \\ \mathrm{H} & 5.185318 & 1.734183 & 1.485584 \\ \mathrm{H} & 6.714653 & -3.503640 & 1.144343 \\ \mathrm{H} & 8.490512 & -2.980653 & -0.539881 \\ \mathrm{H} & 8.725366 & -0.686373 & -1.437482 \\ \mathrm{H} & 7.189824 & 1.136636 & -0.710419 \\ \mathrm{H} & 3.538239 & 0.136306 & 2.854572\end{array}$

